\title{
A Short History of the U.S. Army Adjutant General's Corps 1775-2013
}

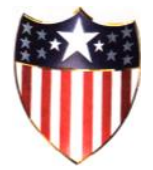

by

Stephen E. Bower, Ph.D.

Staff Historian

U.S. Army Soldier Support Institute 


\section{Report Documentation Page}

Form Approved

OMB No. 0704-0188

Public reporting burden for the collection of information is estimated to average 1 hour per response, including the time for reviewing instructions, searching existing data sources, gathering and maintaining the data needed, and completing and reviewing the collection of information. Send comments regarding this burden estimate or any other aspect of this collection of information,

including suggestions for reducing this burden, to Washington Headquarters Services, Directorate for Information Operations and Reports, 1215 Jefferson Davis Highway, Suite 1204, Arlington

VA 22202-4302. Respondents should be aware that notwithstanding any other provision of law, no person shall be subject to a penalty for failing to comply with a collection of information if it

does not display a currently valid OMB control number.

\begin{tabular}{|c|c|c|}
\hline $\begin{array}{l}\text { 1. REPORT DATE } \\
\mathbf{2 0 1 3}\end{array}$ & $\begin{array}{l}\text { 2. REPORT TYPE } \\
\text { N/A }\end{array}$ & $\begin{array}{l}\text { 3. DATES COVERED } \\
\text { - }\end{array}$ \\
\hline \multirow{3}{*}{\multicolumn{2}{|c|}{$\begin{array}{l}\text { 4. TITLE AND SUBTITLE } \\
\text { A Short History of the U.S. Army Adjutant Generals Corps 1775-2013 }\end{array}$}} & 5a. CONTRACT NUMBER \\
\hline & & 5b. GRANT NUMBER \\
\hline & & 5c. PROGRAM ELEMENT NUMBER \\
\hline \multirow{3}{*}{\multicolumn{2}{|c|}{$\begin{array}{l}\text { 6. AUTHOR(S) } \\
\text { Stephen E. Bower, Ph.D., Staff Historian }\end{array}$}} & 5d. PROJECT NUMBER \\
\hline & & 5e. TASK NUMBER \\
\hline & & 5f. WORK UNIT NUMBER \\
\hline \multicolumn{2}{|c|}{$\begin{array}{l}\text { 7. PERFORMING ORGANIZATION NAME(S) AND ADDRESS(ES) } \\
\text { U.S. Army Soldier Support Institute } \mathbf{1 0 0 0 0} \text { Hampton Parkway Fort } \\
\text { Jackson SC 29207-7050 }\end{array}$} & $\begin{array}{l}\text { 8. PERFORMING ORGANIZATION } \\
\text { REPORT NUMBER }\end{array}$ \\
\hline \multirow{2}{*}{\multicolumn{2}{|c|}{ 9. SPONSORING/MONITORING AGENCY NAME(S) AND ADDRESS(ES) }} & 10. SPONSOR/MONITOR'S ACRONYM(S) \\
\hline & & $\begin{array}{l}\text { 11. SPONSOR/MONITOR'S REPORT } \\
\text { NUMBER(S) }\end{array}$ \\
\hline
\end{tabular}

12. DISTRIBUTION/AVAILABILITY STATEMENT

Approved for public release, distribution unlimited

13. SUPPLEMENTARY NOTES

The history was written by the Command Historian with the intention of assisting the soldiers attending the SSI, Fort Jackson., The original document contains color images.

14. ABSTRACT

This short history covers the U.S. Army Adjutant Generals Corps from the origins through the Global

War on Terror, 2001-2013.

15. SUBJECT TERMS

US Army Adjutant General Corps Human Resources Personnel

\begin{tabular}{|c|c|c|c|c|c|}
\hline \multicolumn{3}{|c|}{ 16. SECURITY CLASSIFICATION OF: } & 17. LIMITATION OF & 18. NUMBER & 19a. NAME OF \\
\hline $\begin{array}{c}\text { a. } R E P O R T \\
\text { unclassified }\end{array}$ & $\begin{array}{c}\text { b. ABSTRACT } \\
\text { unclassified }\end{array}$ & $\begin{array}{c}\text { c. THIS PAGE } \\
\text { unclassified }\end{array}$ & SAR & 68 & \\
\hline
\end{tabular}


BLA N K PAGE 


\section{TABLE OF CONTENTS}

I. THE RIGHT HAND OF THE COMMANDER: 1775-1916

Origins of the U.S. Army Adjutant General's Corps: 1775-1813 . . . . . . . 9

The Adjutant General: $1813-1861 \ldots \ldots \ldots \ldots \ldots \ldots \ldots$

The Formative Years: 1813-1845

The Mexican War and Afterwards: 1846-1860

The Civil War and the Era of Reconstruction: 1861-1902. . . . . . . 15

Adoption of the Branch Insignia

Freedman's Bureau

U.S. Disciplinary Barracks

\section{PERSONNEL SUSTAINMENT: 1916-2013}

The Adjutant General's Department and the General Staff System:

1903-1917 ................................ 22

Military Secretary's Department

National Defense Act of 1916 and Personnel Sustainment

World War I and the Interwar Years: $1917-1940 \ldots \ldots \ldots \ldots \ldots$ 25

Development of Intelligence Testing

Adjutant General for the American Expeditionary Force

World War II and the Beginning of the Cold War: 1941-1950 . . . . . . .

29

The Adjutant General's School

Automatic Data Processing

Special Services

Demobilization of the World War II Army

Establishment of The Adjutant General's Corps

The Adjutant General's Corps and the Cold War: 1950-1991 . . . . . . . 42

The Adjutant General's Doctrine and Review Board

The Adjutant General and the Army Reorganization of 1962

The Adjutant General's Corps Regiment

The Adjutant General's Corps and the Army of Excellence Redesign 
Beyond the Cold War: The Adjutant General's Corps in the $21^{\text {st }}$ Century . . 51

Personnel Transformation and the Adjutant General's Corps

Publication of FM 1-0, Human Resources Support

Global War on Terror: 2001-2013

\section{Appendices}

The Adjutant Generals of the Army: 1775-2013

Commandants, U.S. Army Adjutant General School: 1943-2013 . .

IV. End Notes ...........................62 
Adjutare

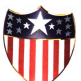

"Old Latin meaning to help, assist or aid. In the military, an adjutant is a staff officer who who assists the commanding officer." 


\section{BLA NK PAGE}




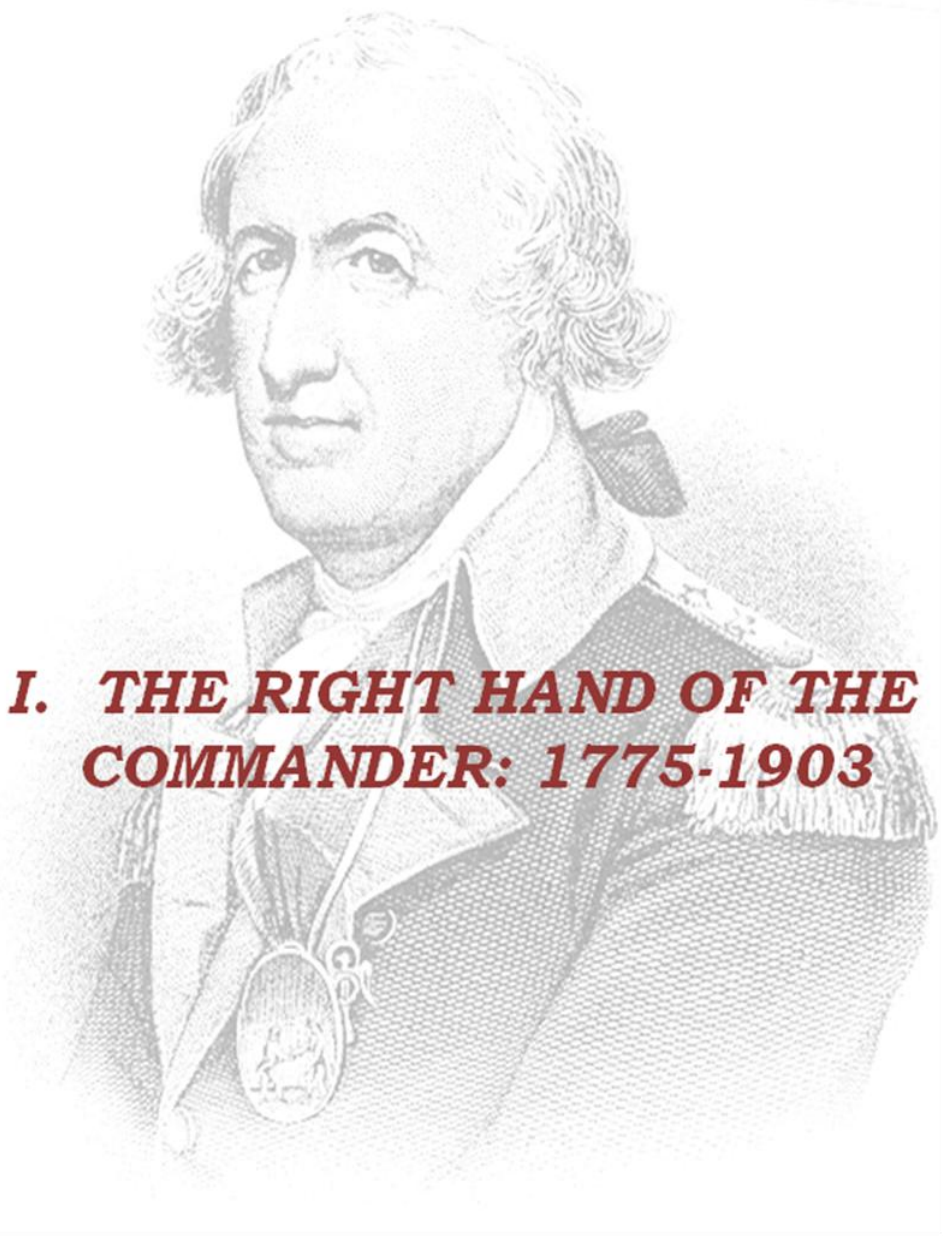


BLA NK PAGE 


\section{Origins of the U.S. Army Adjutant General's Corps 1775-1813}

The origins of the U.S. Army Adjutant General's Corps date back to the American Revolution and and the formation of the Continental Army that General George Washington would command for the duration of the war against Great Britain, 1775-1781. On 16 June 1775 the Continental Congress established the position of Adjutant General on Washington's staff. The following day Congress elected Horatio Gates, a former officer in the British Army, to become the first Adjutant General with the commission of brigadier general. Following Washington, Gates was the second officer to receive a commission in the Continental Army. Subsequently, Gates accompanied Washington to Cambridge, Massachusettes, where on 3 July 1775 Washington assumed command of the Army then laying seige to British forces occupying the city of Boston.

Gates' position was modeled after the British staff adjutant general assigned for each major expeditionary force. Adjutants derived their mission from the old Latin word "adjutare," meaning to assist. In the military sense, it came to mean assistance to the commander in all aspects of military operations. In addition to the administrative duties which would later become his primary focus, the Adjutant was responsible for guards, details, paperwork (including transmission of orders), and the formation of infantry into the line of battle. Gates became the senior brigadier general of the Continental Army and as General Washington's principle assistant brought order and regularity to the fledgling force by transforming the militia units of 13 separate colonies into one "American Army." $1 \mathrm{He}$ 
organized the assembled colonial troops into companies, regiments, brigades; published the Articles of War; prepared instructions for the recruiting service; organized the intelligence service that kept Washington informed of conditions within the British lines; and generally introduced the rule of discipline to the Army. Deputy Adjutants appointed to each of the major departments and for each of the Continental Army corps and divisions modeled their offices after the service performed by General Gates in the early months of the war that would end British colonial rule in America.

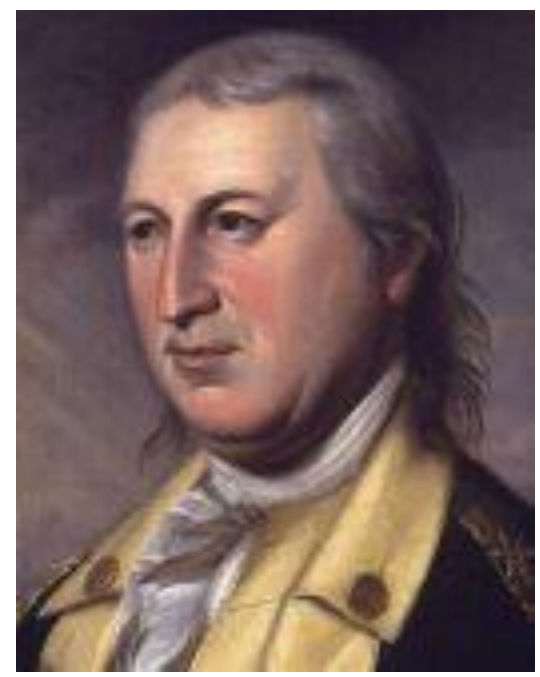

Major General Horatio Gates First Adjutant General of the Army

One of Horatio Gates' first and most difficult tasks as Washington's Adjutant was the compiling of an initial strength report (return in 18th century terminology) of the Continental Army. Adjutant Gates developed the system by which regular returns were compiled and reported up through the Continental Army's chain-of-command. The first report was completed on 19 July 1775, and established the basis of the "personnel system" used to 
compile personnel and strength information for the remainder of the war. "Without those Returns," Washington surmised, "it is impossible that the business of the Army can be conducted with any degree of regularity or propriety."2

Prior to the formation of the General Staff System in the early $20^{\text {th }}$ Century, Gates' example would inform the duties of subsequent Adjutants who would act more along the lines of what today we recognize as a Chief of Staff, "the Right Hand of the Commander." In fact, Brigadier General Henry C. Corbin, Adjutant General of the Army during the SpanishAmerican War (1898-1904) performed as such for Secretary of War Elihu Root and President William McKinley. During a time of national crisis, Corbin, as described by one historian, became " the most powerful professional soldier in the Army" One prominent member of the McKinley Cabinet wrote to Secretary of War, Elihu Root, saying Corbin's “most valuable service" to the nation was "in giving the President the benefit of his knowledge and judgement, and in carrying out the President's wishes and commands through the proper channels."

\section{The Adjutant General: 1813-1861}

\section{The Formative Years: 1813-1845}

Mobilization for the War of 1812 forced the War Department to hard line the duties of the general staff which included among others the Adjutant General. Lieutenant Colonel Alexander Macomb, the acting Adjutant General at the time, enumerated his duties to include the forming of "all orders given by the Commanding General in a perspicuous manner; to 
forward them with dispatch; to publish the decisions on the sentence of general courts-martial; to make out all the details for the distribution of service, equally between the different corps of the Army; to receive the daily and monthly returns, and lay abstracts before the Commanding General; to draw up instructions; to furnish watch-words; to give form to correspondence with the Secretary of War, Generals and the staff officers; to receive all applications for furloughs, and other particular requests; to correspond with relations of soldiers; to preserve orders, instructions, printed documents, and letters; to make the monthly returns of the Army, and to prescribe forms of the returns exhibiting strength of the Corps."

In March 1813, in the course of the second war with Great Britain, Congress established the Adjutant General's Department and the remaining "general staff of the Army." The legislation provided for an adjutant and inspector-general with the rank of a brigadier-general. The Adjutant General would be provided a staff not to exceed eight adjutants-general with the rank of colonel and sixteen assistant adjutants-general with the brevet rank of major of cavalry. ${ }^{5}$ The act further authorized the President to to assign either the adjutant or inspector general to the principal Army of the United States "who should, in such case, act as adjutant and inspector-general, and as chief of the staff of such Army." The Adjutant General's peacetime mission, in particular, would increase throughout the $19^{\text {th }}$ Century in relation to the nation's lengthening military record and the number of Americans with previous military service.

The early $19^{\text {th }}$ Century mission of the Adjutant General's Department was defined largely by the career of Major General Roger Jones, a highly distinguished veteran of the War of 1812. Jones became 
Adjutant General of the Army in 1825 and served in that capacity until his death in 1852 .

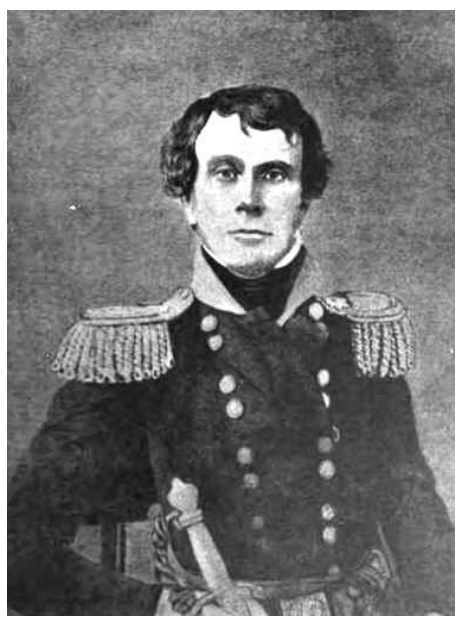

Major General Roger Jones, Sr.

Adjutant General of the Army 1825-1852

During his 27-year tenure, Jones developed the office of the Adjutant General into the central coordinating bureau of the War Department that stood unofficially between the other bureaus and the Secretary of War, a process facilitated by proximity to the Secretary and the Army's commanding general and the fact that nearly all communications going to and from the War Department passed through the Adjutant General. In 1828, Congress assigned Jones and the Adjutant General's staff the task of preparing the annual budget of the Recruiting Service. In 1847, the Department assumed responsibility for the entire service to include recruiting depots and the organization of recruits into companies and regiments, a mission associated with the Adjutant General for more than 100 years and until the formation of the U.S. Army Recruiting Command in October 1964. 


\section{The Mexican War and Afterwards: 1846-1860}

During the Mexican War (1846-1847), 14 officers served in the Adjutant General's Department while a total of 13 assistant adjutants served commanders of American armies in the field. In 1851 following the war, Adjutant General Jones became the ex officio commissioner of the newly established asylum for the relief and support of invalid and disabled soldiers, a soldier's home made possible in part by the financial contributions of General Winfield Scott who contributed $\$ 100,000$ of the $\$ 150,000$ he received in tribute money from the Mexican government for not ransacking Mexico City at the conclusion of the war. Scott, Major Robert Anderson, Commander of Fort Sumter, South Carolina where the first shots of the Civil War were fired, and Senator Jefferson Davis, later to become President of the Confederate States of America, are usually credited with the moral energy for getting the Soldiers' Home established. In 1883, the Adjutant General, Brigadier General R.C. Drum, was appointed to serve on its Board of Commissioners. ${ }^{7}$

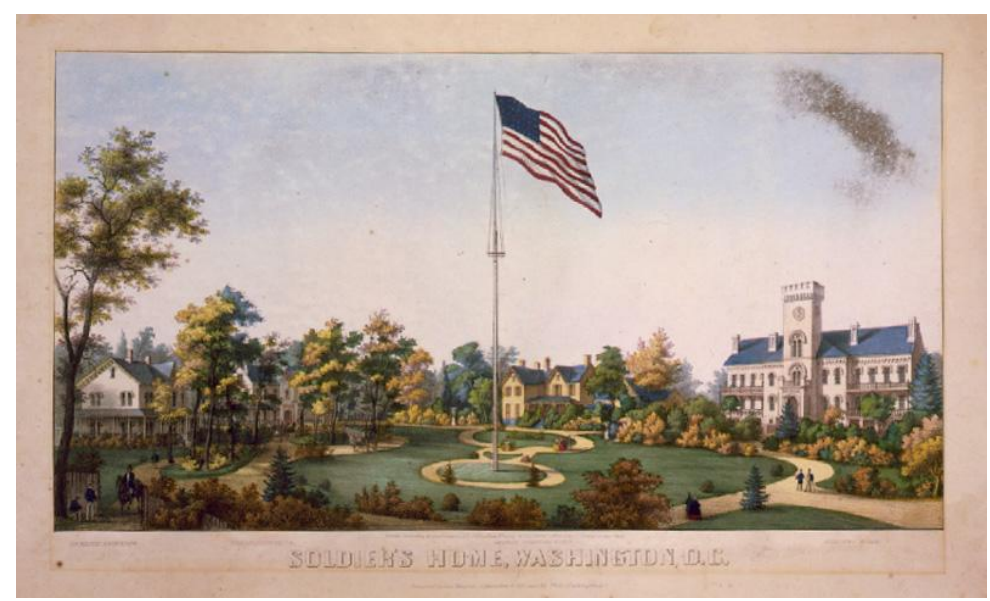

U.S. Soldier's Home established in 1851 The Adjutant General of the Army served as Commissioner 


\section{The Civil War and the Era of Reconstruction: 1861-1902}

During the War Between the States the Adjutant General's Department shared the task of mobilizing troops with the Adjutant General from each of the respective states. State militias were still under the authority of the state governors. Under this system, the Federal Government issued calls for troops, but the Governors and their Adjutant Generals were responsible for recruiting and initially equipping the troops until they were mustered into service. State Adjutant Generals kept records of each citizen who served in Civil War armies. Following the war, however, the Adjutant General's Department became responsible for creating and maintaining the personnel records of serving soldiers for the purposes of pensions. Most of the information for these records was provided by "muster rolls" produced by the various state regiments during the course of the war. Forty-four years later in 1909, the Adjutant General's Department finally completed the task.

\begin{tabular}{|c|l|c|c|l|}
\hline Name & Rank & $\begin{array}{c}\text { Date of Muster } \\
\text { Into Service }\end{array}$ & Term/ Years & \multicolumn{1}{|c|}{ Remarks } \\
\hline John W. Smith & Capt & August 11, 1861 & 3 & Resigned September 20, 1861 \\
\hline $\begin{array}{c}\text { Sylv. D. } \\
\text { Barrows }\end{array}$ & 1st Lt. & August 11, 1861 & 3 & $\begin{array}{l}\text { Promoted to Major, November } \\
15,1861\end{array}$ \\
\hline $\begin{array}{c}\text { Marcus L. } \\
\text { French }\end{array}$ & 2d Lt. & August 11, 1861 & 3 & $\begin{array}{l}\text { Lieut. Company D, November 15, } \\
\text { 1861; to Captain Company E, } \\
\text { April 2, 1862 }\end{array}$ \\
\hline $\begin{array}{c}\text { Wm. F. } \\
\text { Butcher }\end{array}$ & 2d Lt. & August 11, 1861 & 3 & $\begin{array}{l}\text { Promoted from 1st Sergeant July } \\
\text { 1, 1862; killed at Cedar Mountain, } \\
\text { Va., August 9, 1862 }\end{array}$ \\
\hline
\end{tabular}

Partial Muster Roll

Company $D, 1^{\text {st }}$ Pennsylvania Cavalry 
Brigadier General Lorenzo Thomas, General Winfield Scott's chief of staff, was appointed Adjutant General of the Army in March 1861 one month before the beginning of hostilities. He served in that capacity until his retirement in 1869. In March 1863, following the issuance of the Emancipation Proclamation, the Secretary of War sent him on temporary duty to recruit and organize African-American troops in the Military Division of the Mississippi. Under Thomas' direction, the War Department's Bureau of Colored Troops was established. By the end of the war, Thomas had recruited more than 75,000 of the nearly 180,000 African-American soldiers who served in Union armies.

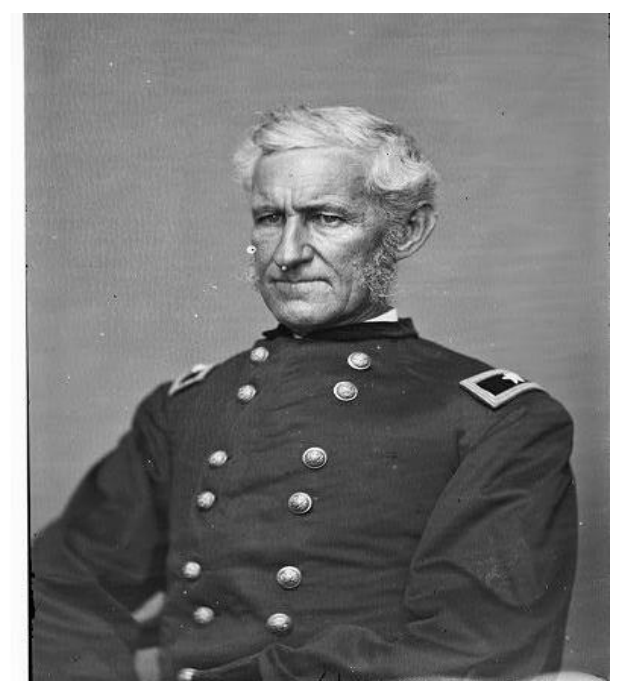

Major General Lorenzo Thomas Adjutant General of the Army during the Civil War 1861-1869

Thomas was breveted a major-general following the war in recognition of his military service. As Adjutant General of the Army he found himself in the middle of the heated politics surrounding the attempted impeachment of President Andrew Johnson and the fight to control the Reconstruction process in the South. When President Johnson decided to fire Secretary of War Edwin M. Stanton in February 1868, he nominated 
Adjutant General Thomas to replace him. Thomas is said to have personally delivered the President's dismissal notice to Stanton, but the Secretary refused to accept its legitimacy. Instead, he barricaded himself in his office and had Thomas arrested for violating the Tenure of Office Act. Stanton later dropped the charges when he realized they would not hold. ${ }^{8}$

During Thomas' war-time assignment to the field, Thomas' deputy, Brigadier General Edward D. Townsend, served as both Adjutant General and principal executive officer of the War Department. In that capacity he was in constant contact with President Lincoln and Secretary of War Stanton. After Abraham Lincoln's assassination in April 1865, Townsend represented the Army at the various funerals for the fallen President. When Thomas retired in 1869, Townsend succeeded him as the Adjutant General. Under Townsend's direction, the Adjutant General's Department, began compiling the voluminous records of the war detailing the activities of the government and armies of both North and South. The "Official Records of the War of the Rebellion" became an invaluable contribution to American military history. Work began in 1864 and was finished in 1901 years after Townsend had retired from the Army. The project resulted in 138,579 pages, 1,006 maps and diagrams. The pages were assembled in 130 books, organized into 70 volumes and grouped in four series.

\section{Adoption of the Branch Insignia}

On December 14th, 1872, Brigadier General Townsend officiated over the Adjutant General's Department adoption of the old topographic engineer shield as its own insignia. The insignia became available upon the integration of the Topographical Engineers into the larger Corps of 
Engineers in 1863. Thirteen embossed stars, one large surrounded by 12 smaller stars and representing the original thirteen colonies, replaced the "T.E." on the upper shield. The 13 verticle stripes, 7 silver and 6 red in the lower two thirds of the shield, remained a fixure of the insignia of service worn by all Adjutant General's Corps officers to this day. ${ }^{9}$

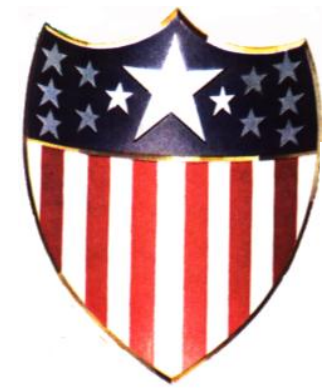

\author{
Branch Insignia \\ Adjutant General's Department \\ 14 December 1872
}

\title{
Freedman's Bureau
}

Also in 1872, the Adjutant's General's Department inherited the mission of the Bureau of Refugees, Freedmen, and Abandoned Lands established in March 1865 following the war. More commonly known as the "Freedman's Bureau," the agency supervised all relief and educational activities relating to freed slaves and refugees. When the agency was formally abolished, its remaining functions were invested in the Freedmen's Branch of the Adjutant General's Department. Included among them was responsibility for filing claims of African-American soldiers and sailors for bounties, back pay, or pensions. ${ }^{10}$ The Freedman's Branch did such a good job of schooling the former slaves the Army in 1881 assigned the Adjutant General the task of setting up and supervising a military school system. By 1882, 147 schools had been established with an enrollment of 975 enlisted soldiers and 1,100 children. 


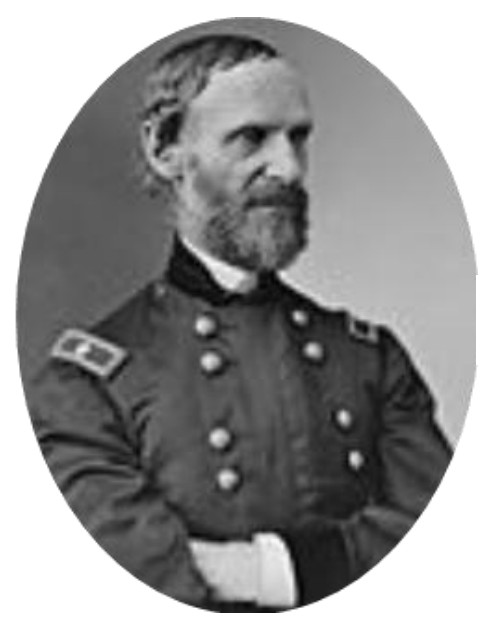

\author{
Brigadier General E. D. Townsend
} Adjutant General of the Army: 1869-1880

\title{
U.S. Disciplinary Barracks
}

As Adjutant General of the Army, Townsend directed the development and implementation of plans to establish a military prison at Fort Leavenworth, Kansas. Originally the United States Military Prison, the facility was renamed the United States Disciplinary Barracks (USDB) in 1915. It remains the only maximum security prison in the Department of Defense. The USDB began operations in May 1875 under the supervision of the Army's Adjutant General. Today, it survives as the oldest penal institution in continuous operation in the federal system. 


\section{BLANK PAGE}




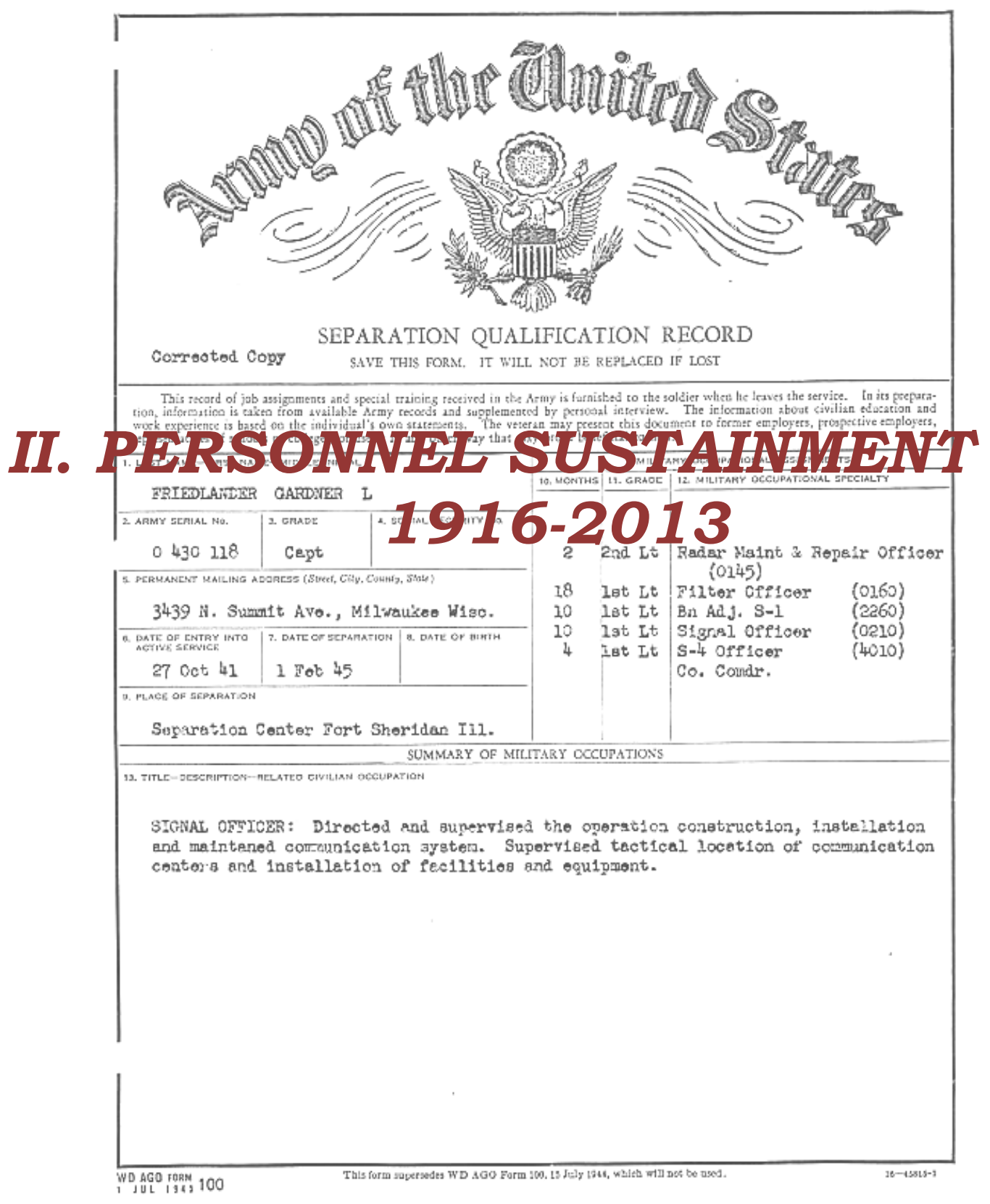




\section{The Adjutant General's Department: and the General Staff System: 1903-1917}

Following the Spanish-American War, Secretary of War Elihu Root spearheaded a major reform movement in the War Department that culminated in the 1903 adoption of the Army general staff system modeled after the command and staff systems employed by many European armies. With the advent of the general staff, the Secretary of War increasingly turned to it for advice and plans related to "the raising, training, and equipping the Army" to include all matters related to personnel and administration. ${ }^{11}$ Under the new system, many of the duties of the Adjutant General were reassigned to the Chief of Staff of the Army, most notably the Military Information (Intelligence) Division that had been part of the Adjutant General's Department since $1886 .{ }^{12}$ As a special staff officer in the new system, the Adjutant General assumed management of the recruiting service and all personnel and unit records relative to the current force. The new reforms formally designated the War Department's Records and Pensions Office as the manager of the ever-expanding collection of personnel records (regular and militia) of officers and enlisted soldiers who had previously served in the military. ${ }^{13}$

The Militia Act of 1903, another reform measure sponsored by Ohio Senator Charles Dick, federalized the state militias and required them to organize their units along the lines of the Regular Army. Consequently, the Act made militia units subject to Federal inspection. War Department oversite of militia affairs fell to the Adjutant General. An office composed of an Army major and four civilian clerks in the Miscellaneou Division of the Adjutant General's Department became responsible for the task. 
Predecessor to today's National Guard Bureau, the small office detailed Regular Army officers to inspect militia encampments, preserved inspection reports, and prepared militia annual returns required by Congress.

\section{Military Secretary's Department}

Congress disestablished the Adjutant General's Department completely in 1904 and in its place created the Military Secretary's Department. The name change also occasioned the appointment of Major General Frederick C. Ainsworth, Chief of Pensions and Records, as the Military Secretary. Ainsworth's appointment marked the consolidation of all military records in the office of the Military Secretary. As Military Secretary, Ainsworth was charged "with all duties pertaining to the command, discipline, and administration of the existing military establishment, all communications with troops, the issuing of all orders, the recruiting service, prisoners, all records and pensions, and historical records." 14 The history of the Military Secretary's Department was brief lasting only until 2 March 1907 when it was redesignated as "The Adjutant General's Department." Accordingly, the Military Secretary was redesignated "The Adjutant General" with new and special emphasis on "The." In 1908 the War Department established a Division of Militia Affairs that relieved the Adjutant General of oversite of the organized militia and its personnel records.

Following Ainsworth's retirement in 1912, The Adjutant General's Department expanded its record keeping mission by inheriting responsibility for maintaining the personnel records of citizen-soldiers assigned to the Army Reserve force established in 1908 and collecting, classifying, and publishing the military records of the Revolutionary War to include 
personnel records of militia troops from the former colonies. Staffed in 1915 with five permanently assigned and eighteen detailed officers serving four-year tours of duty, The Adjutant General's Department employed a clerical force of nearly 500 civilian personnel most of whom were involved in records management. ${ }^{15}$

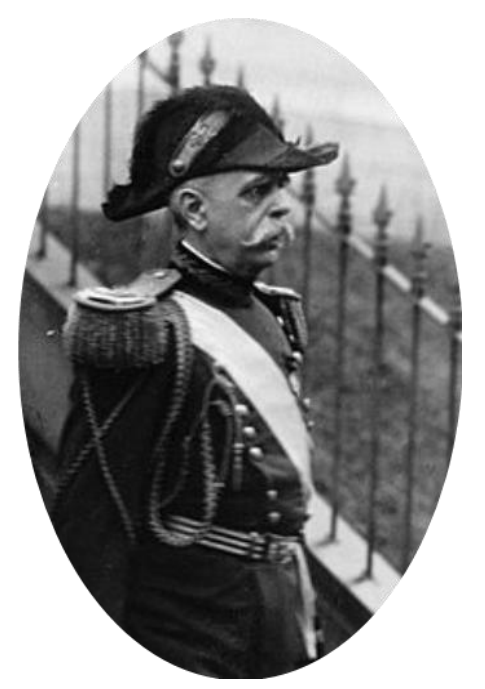

Major General Frederick C. Ainsworth The Military Secretary (1904-1907) The Adjutant General (1907-1912)

\section{National Defense Act of 1916 and Personnel Sustainment}

The National Defense Act of 1916 set the rank of The Adjutant General at Major General and provided for an assistant at the rank of Brigadier General to direct the Department's Personnel Bureau. The legislation also assigned The Adjutant General responsibility for all functions relative to the "personnel sustainment" of the Army -- the procurement, assignment, promotion, transfer, retirement, and discharge of all officers and enlisted personnel. From this moment on, The Adjutant General and the soldiers and civilians who worked for the office entered into a new era. Rather than the "right hand of the commander," The Adjutant 
General of the Army became the principal staff officer responsible for the managing the U.S. Army's personnel system.

\section{World War I: 1917-1919}

\section{Development of Intelligence Testing}

The Adjutant General's Department under the leadership of Major General Henry P. McCain pioneered the use of intelligence tests during World War I to facilitate the induction, classification, and assignment of troops for military service. Professional psychologists drafted into the Army and assigned to The Adjutant General's Department developed group intelligence tests in conjunction with the military draft authorized by the

Selective Service Act of $1917 .{ }^{16}$ By the end of the war, some 24 million men had registered, and some 2.8 million had been drafted. Psychologists developed two different tests to measure the skills and abilities of the soldier, the Alpha Test consisting of 212 multiple-choice and true-false questions, said to measure general intelligence, and the Beta Test, composed mostly of pictures and diagrams, for draftees who could not read or write.

By war's end approximately two million men had taken the tests. ${ }^{17}$ The Army Alpha and Beta testing program represented a defining moment in the history of psychology. As the first widespread use of intelligence testing, it popularized the use of such instruments to assign individuals to certain jobs or tasks for which their measured intelligence seemed to fit them. These tests were the precursors of modern standardized tests like the Scholastic 
Aptitude Test (SAT) and the Armed Services Vocational Aptitude Battery (ASVAB).

Major General Henry P. McCain The Adjutant General of the Army: 1914-1918

"Father of the Selective Service System"

As a result of World War I, the Army began adopting many of the practices employed by the modern business corporation. Among them was the utilization of trained personnel specialists to recruit and manage the corporate work force by skill, ability, and qualification. "Personnel" as a specialty within the Army became the domain of adjutants general. Each World War I Army corps, division, and regimental adjutant was authorized a personnel officer and staff whose responsibility was to procure, classify, and assign incoming personnel. Moreover, the personnel officer managed the unit's overall strength. He tracked casualties, identified the need for particular replacement personnel, procured them, and assigned them within the unit. The personnel specialist also accounted for all transfers, promotions, demotions, and discharge of individual soldiers. ${ }^{18}$

\section{Adjutant General for the American Expeditionary Force}

Brigadier General Benjamin Alvord, son of the Union Paymaster General during the Civil War, deployed the theater Adjutant General Office 
to France in June 1917 to support the American Expeditionary Force (A.E.F.) during World War I. Theater Adjutant General operations expanded overtime but eventually grew to reflect the duties and functions of The Adjutant General's Department in the War Department. The organization initially included the following divisions or functions -Commissioned and Enlisted Personnel, Returns and Strength Reports, Correspondence, Statistical, War Prison Barracks, Captured Property, Returns for Prisoners, Prisoners' Inquiry Office, Recruits, Muster Rolls, Disposal of Records of Small Units, Correspondence, Records, Postal Affairs, Printing Office, and the Y.M.C.A. As the theater army matured, Alvord and his staff, similar to the modern day Secretary General Staff (SGS), also assumed the administrative task of coordinating the work of General John J. Pershing, A.E.F. commander, and his different staff sections. $^{19}$

On 1 May 1918, Colonel Robert C. Davis succeeded Brigadier General Alvord as The Adjutant General of the A.E.F. Promoted to Brigadier General in June, Davis oversaw the expansion of Adjutant General operations to accommodate the huge and continuous influx of military personnel into and out of the theater of operations. The variety and volume of work associated with Adjutant General operations was illustrated by the growth of the organization. By the end of December 1918, the theater Adjutant General's organization included the following divisions: Officers, Enlisted, Personnel, Miscellaneous, Statistical, Records, Code, Cable, Mail, Orders, Printing, Permits, Postal Express, and Motor Dispatch.

The Central Records Office among the operating agencies of the Adjutant General evolved into the "largest single administrative unit in the 
Allied Armies." It maintained personnel information on each of the more than 4 million individuals that served in the American Expeditionary Force to include the time of arrival, assignments, medical history, location and mail address, and casualty information. It grew from one officer supported by one clerk to nearly six thousand officers and enlisted men and over five hundred women from the Women's Army Auxiliary Corps (WAAC) from Great Britain. ${ }^{20}$ To establish the World War I personnel system, the Central Records Division detached "statistical sections" or detachments to ensure that combatant units properly prepared organization rosters, change of station reports, statistical cards, daily casualty reports, strength returns, and weekly reports from hospitals. ${ }^{21}$

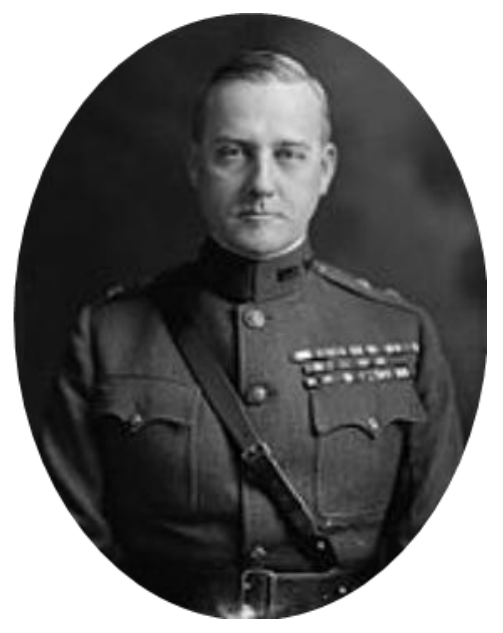

Major General Robert C. Davis
Adjutant General A.E.F (1918-1919)
The Adjutant General (1922-1927)

Casualty information collected and verified by the Central Records Division established a precedent for accuracy by which all subsequent systems designed to report wartime casualties would be measured. "Realizing the importance of correct reports to families in America," Brigadier General Davis took a personal interest in the system that 
generated casualty information. All casualty information was directed to the Central Records Division, but it was also the responsibility of Division personnel to verify the accuracy of reports that came from a variety of sources but often proved unreliable and contradictory. At least 10 percent of all reports proved to be inaccurate and a full 15 percent were "so faulty in spelling or wanting of data as to make them useless." Central Records Division personnel ultimately processed more than 300,000 casualty reports during the war. ${ }^{22}$

After the signing of the armistice on 18 November 1918, The Adjutant General's Department proceeded to demobilize the huge military force that had been assembled to fight the war. By the beginning of December, The Adjutant General's Department had printed and distributed more than 12 million forms necessary to the task. One year following the end of the war, 26 separation centers had demobilized an army of 3,422,233 soldiers. $^{23}$

\section{World War II and the Beginning of the Cold War 1941-1950}

World War II, said Major General James A. Ulio, has required The Adjutant General's Department to undertake duties "undreamed of in Horatio Gates' philosophy." Ulio, The Adjutant General of the Army during

World War II, knew full well of what he spoke. The simple multiplication of actions required by the increase of our Army from fewer than 200,000 to several million men in less than two years, continued Ulio, has "required a vast enlargement in the scope and volume of work which The Adjutant General's Department administers." Indeed, approximately 11 million men 
and women served in the Army and the Army Air Corps during the war. ${ }^{24}$ The number, variety, and complexity of tasks assigned to The Adjutant General's Department was simply unprecedented.

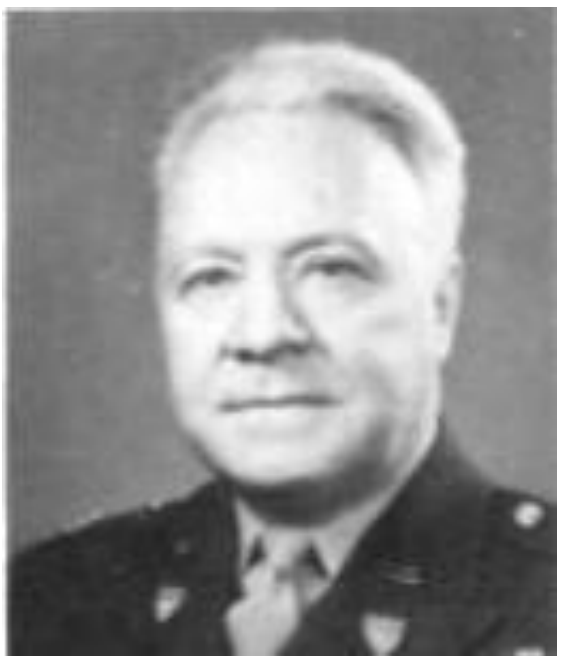

Major General James A. Ulio The Adjutant General of the Army 1942-1946

Following the Japanese attack on Pearl Harbor and American entry into the war in December 1941, the War Department underwent a major reorganization intended to put it on a war footing. The Army Reorganization Act of 9 March 1942 realigned The Adjutant General under the commanding general of the Army Service Forces (ASF) while retaining him as a member of the War Department special staff. In this capacity he acted as The Adjutant General of the Army as well as Adjutant General for the ASF. ${ }^{25}$ The ASF became the massive logistical and personnel services support organization responsible for sustaining the U.S. Army operations in all theaters of war. The ASF, Army Ground Forces, and the Army Air Forces were the three major World War II Army commands that prosecuted the war 
against Germany and Japan. In addition to supply and transportation, the reorganization delegated to the Commanding General, Army Service Forces "the administration of all functions which are Army-wide in scope and which pertain to personnel as individuals, both military and civilian." ${ }^{26}$ The latter, of course, embracing much of the mission performed by The Adjutant General's Department and the soldiers assigned to it during the war.

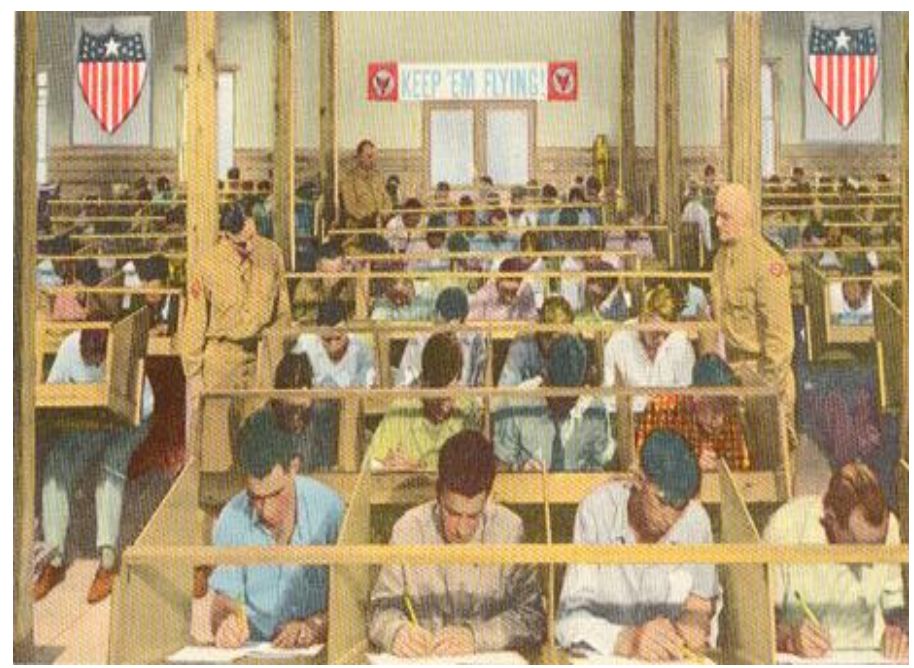

Adjutant General's Department WWII Induction and Reception Center Fort Benjamin Harrison, In 1943

Major General Ulio's name may have been the most recognized of any military official during the war. His name was affixed to every Western Union telegram and letter of condolence sent to family members who grieved the loss of a husband or son during the war. Ulio stood at the top of a wartime casualty reporting system that began with the recording of the soldier's death at the company level and ended with The Adjutant General's Department notifying the family of their loss. Ulio's staff notified the next of kin of more than 400,000 soldiers and airmen who died in the course of 
the war. ${ }^{27}$ In addition to providing staff officers in Army units from Theater level down to the regiment that managed strength and casualty reporting systems and provided personnel support services to commanders and individual soldiers, The Adjutant General's Department fielded a variety of troop in all theaters of war to include replacement depots, battalions, and companies; machine record units, postal units, courier service units and Army bands. The fielding of troops and organizations belonging to The Adjutant General during the war necessitated the assignment of enlisted personnel to the Adjutant General's Department for the first time in history. ${ }^{28}$

\section{The Adjutant General's School}

On 3 March 1941 The Adjutant General of the Army, Major General Emory S. Adams advised Assistant Chief of Staff, G-3, Brigadier General Harry L. Twaddle that "in the past the training of administrative personnel of the Army . . . has been effected at various administrative headquarters of all echelons through practical experience gained on administrative duties. This system was effective in time of peace. Under the emergency situation, however, the system is no longer effective, either for commissioned personnel or enlisted administrative personnel." Adams was specifying the need for a specialty school to train soldiers to perform The Adjutant General's wartime personnel and administrative mission. Subsequently, The Adjutant General's School was established on 14 June 1941 at Arlington Cantonment, Virginia. Courses authorized at that time were administration; classification; machine records; postal; personnel consultant, and recruiting. The authorized training capacity was 200 students composed principally of officers. Later that year, The Adjutant General's School began warrant officer bandleader training for enlisted personnel. 
The school's coat of arms, adopted on March 10, 1942, consisted of a "right arm encased in armor with hand holding [a] sword, overlaid with the shield of the Adjutant General's Department." The armor and sword were gold. The crest symbolized the position of an Adjutant General as the strong right arm of the commander who wielded the sword of authority in his name. The crest and shield were joined by a wreath of six alternating twists of gold and blue. A torch on a shield of gold and blue symbolized knowledge and the role of the school in bringing "enlightenment in the field of its instructional mission." In red lettering against a gold background, designers stretched the school's motto, "Ut Adjuvemus Discimus" ("We Learn In Order That We May Aid Others"), across the bottom of the coat of arms.

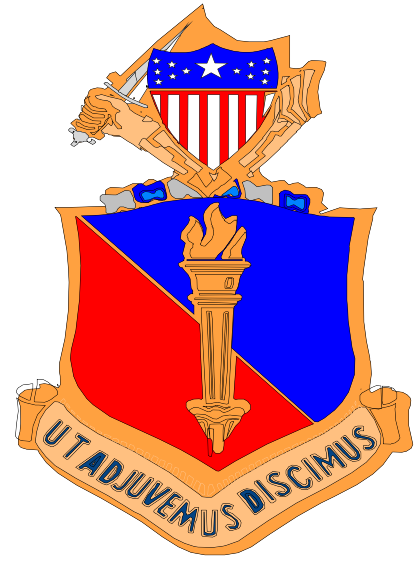

The Adjutant General's School Coat of Arms 10 March 1942

The school moved many times during the course of the war; first, in January 1942 to Fort Washington, Maryland. In a series of moves between 1944 and 1947, the school called five different locations "home;" Fort Sam Houston, Texas (August 1944); Camp Lee, Virginia (April 1945); Fort Oglethorpe, Georgia (August 1945); Carlisle Barracks, Pennsylvania 
(November 1946); and finally back to Camp Lee in September 1947 where it was colocated with the Quartermaster School. Increasing student loads and expanding Quartermaster activities caused by the Korean War eventually forced the school to move to Fort Benjamin Harrison, Indiana, in March $1951 .^{29}$

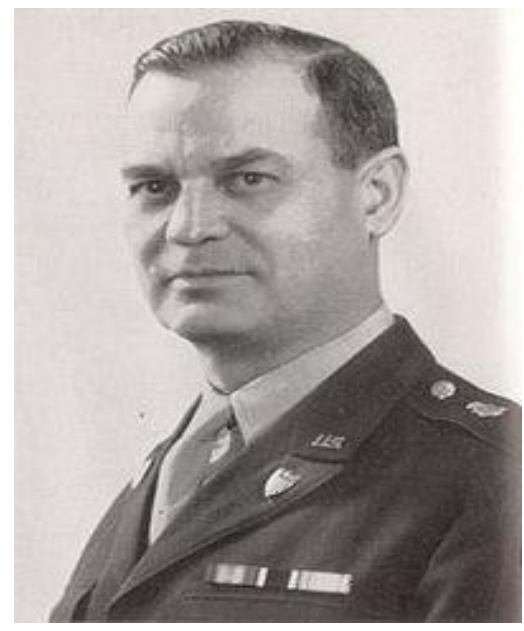

Brigadier General Herbert C. Holdridge $1^{\text {st }}$ Commandant, AGS 1942-1943

Brigadier General Herbert C. Holdridge served as the school's first commandant during its time at Fort Washington, a logical extension of his previous job as Plans and Training director for The Adjutant General's Department. A Westpoint classmate of Dwight D. Eisenhower and Matthew B. Ridgeway, Holdridge directed the establishment of the school and its various satelite branches around the country as the nation mobilized for war and the need for personnel and administrative specialists accelerated. ${ }^{30}$ In retirement Holdridge became an accomplished writer and gadfly politician who twice ran for the presidency as a third party candidate. His daughter Cheryl, an accomplished dancer and actress achieved celebrity status during the 1950's and 1960's first, as an original Mouseketter on the Mickey 
Mouse Club, and second, as Wally Cleaver's girl friend on the popular longrunning television series "Leave It to Beaver."

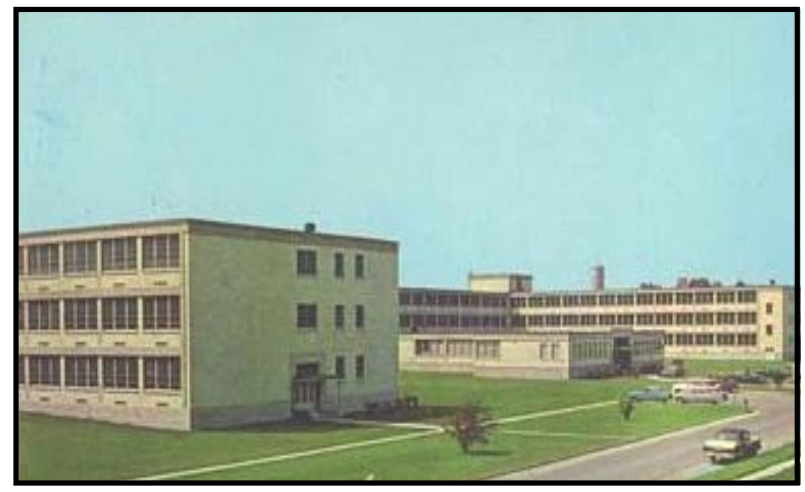

Gates-Lord Hall, Fort Benjamin Harrison, IN Home the Adjutant General School 1957-1995

On 27 February 1957, the school began operations in what was then the third largest building owned by the Department of Defense. Built at a cost of $\$ 4,400,000$, the building also housed the Army's Finance School. Named Gates-Lord Hall after the first Adjutant General of the Army, Major General Horatio Gates and the Army's first Chief of Finance, Brigadier General Herbert M. Lord, the building possessed more than 50 classrooms and more than 300,000 square feet of floor space,. The school remained at Fort Harrison for 43 years until a Base Realignment and Closure review in 1991 resulted in the closing of the installation and the transfer of the Adjutant General School to Fort Jackson, South Carolina. School personnel completed the move in October of 1995.

\section{Automatic Data Processing}


During World War II, the Adjutant General's Department pioneered the use of automated data processing systems that mechanized much of the manual system necessary to record wartime personnel information. The Machine Records Section of The Adjutant General's Department began operating on 15 November 1940. Subsequently, electronic accounting machines were tested during the famous Louisiana Maneuvers in the summer of 1941. Mobile machine records units became the primary system used for personnel accounting in the field. During the war, 62 mobile machine records units and 28 fixed machine record units at all echelons of command were manned by officers and enlisted soldiers assigned to the Adjutant General's Department. The wartime course in Machine Record Units offered by The Adjutant General's School provided the first inter-service training in electronic accounting machine operations.

By 1942 Machine Records Units had become an integral part of the Army personnel system. The efficient and successful operation of these units was dependent upon a highly trained crew of operators properly supervised by trained officers familiar with electronic accounting machines and their emerging role in the manufacture of daily unit rosters; strength returns, and casualty reports. Following the war, the school began offering instruction in the new field of computer science graduating the first generation of military information management specialists. In fact, The Adjutant General's School throughout the period of the Cold War was instrumental in integrating information and computer technology into the force and developing training programs that prepared soldiers to use it. As one Adjutant General officer predicted after World War II, automated data processing equipment would become commonplace in the Army in the years to come. In 1966 the Adjutant General's Corps was given Army proponent responsibility for 
automatic data processing (ADP) management and operations to include training, MOS (military occupational specialty) development, and for developing other ADP applications for the Army. In July 1986, the Adjutant General's Corps at the direction of the Commander, U.S. Army Training and Doctrine Command passed the training and proponent responsibility of the information and records management function to the Army's Signal Corps at Fort Gordon, Georgia. ${ }^{31}$

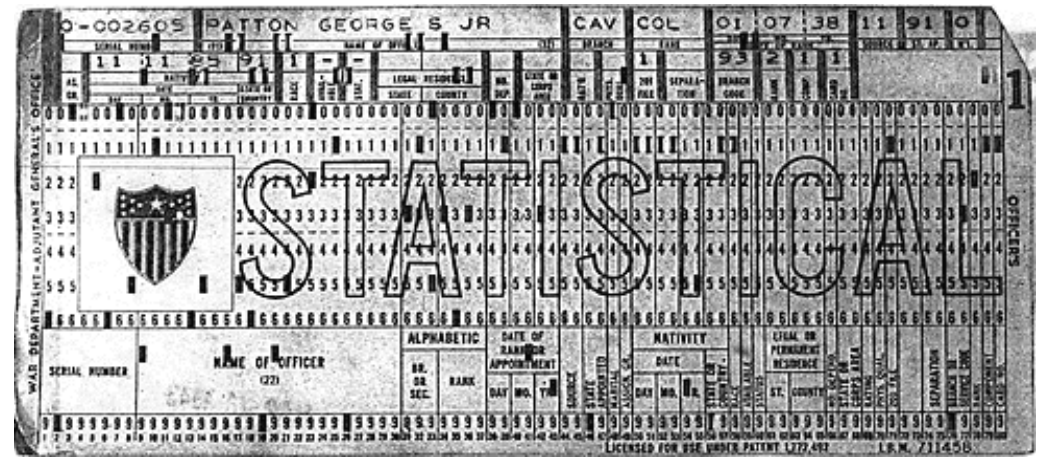

The IBM Punch Card used by Machine Records Units during World War II. It was made of heavy, stiff, stock paper, measuring 3-1/4" high by 7-3/8" wide with 80 columns numbered left to right and 12 rows from top to bottom. ${ }^{1}$ This one was prepared on 7 January 1938 for George S. Patton, Jr., Colonel of Cavalry.

\section{Special Services}

In July 1940 The Adjutant General's Department established the "Morale Division" aimed at the alleviation of "mental stresses and strains from the minds of soldiers, and inculcating in them a high esprit de corps." 32 Colonel Henry H. Pfeil, first Chief of the Morale Division assumed the task of providing morale support services to the U.S. Army during and after the mobilization period. His task obviously became more complicated after the bombing of Pearl Harbor in December 1941. Pfeil and his staff employed motion pictures, ping-pong, baseball, pool tables, and camp huts built for 
dancing and games to offset the frequent depression caused by extended separation of soldiers from family and friends.

Built upon lessons learned in the American Expeditionary Force of World War I, the program as the Army's own aimed to eliminate the waste and duplication of effort among the various social welfare agencies like the YMCA and the Salvation Army that served soldiers during World War I. Later expanded and renamed the Special Services Division in January 1942, the primary mission of the wartime program was to "keep the boys from getting homesick." 33 The expanded Special Services Division was comprised of the Athletic and Recreation Branches and included among its many programs and activities athletics, dramatics, music, and welfare; publications; facilities; troop information; and motion pictures. Throughout the war, the Army trained its Special Services specialists at Fort Meade, Maryland..$^{34}$

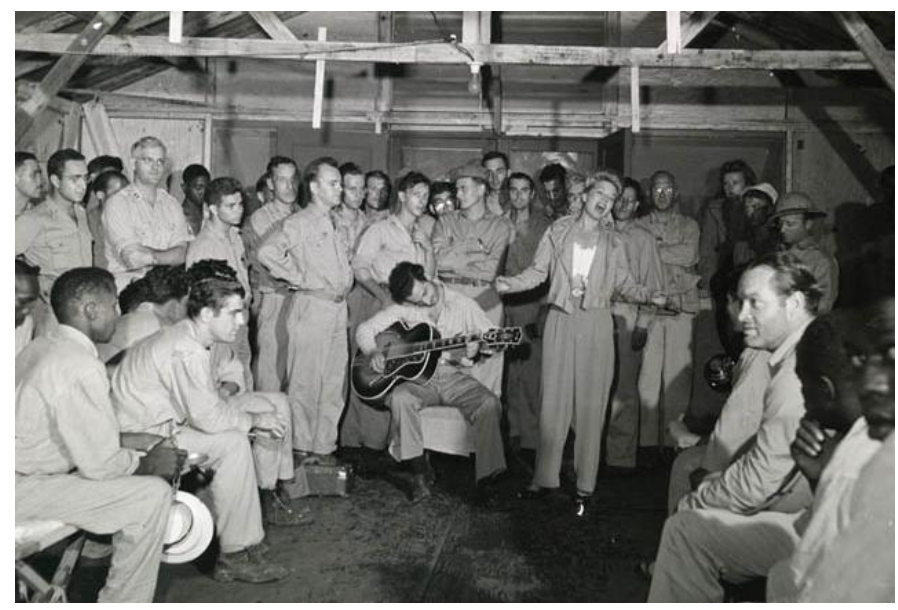

Special Services

Bob Hope and company entertaining the troops during World War II 
Lieutenant Colonel Howard C. Bronson, professional musician and former member of the famed John Phillip Sousa Band headed the Music program for the Chief of Special Services. Although Bronson's mission embraced more than Army bands, they became his principle focus, fielding and sustaining the approximately 500 bands that served the Army during the war. ${ }^{35}$ In this capacity, Bronson is generally considered to be the first Chief of Army Bands, a duty currently performed by the Commandant of the Adjutant General School, but associated with the Adjutant General mission since World War II. Those who followed him into the office believed like him that music was "one one of the vital requisites of a people determined to make and supply its fighters with the tools of warfare." 36

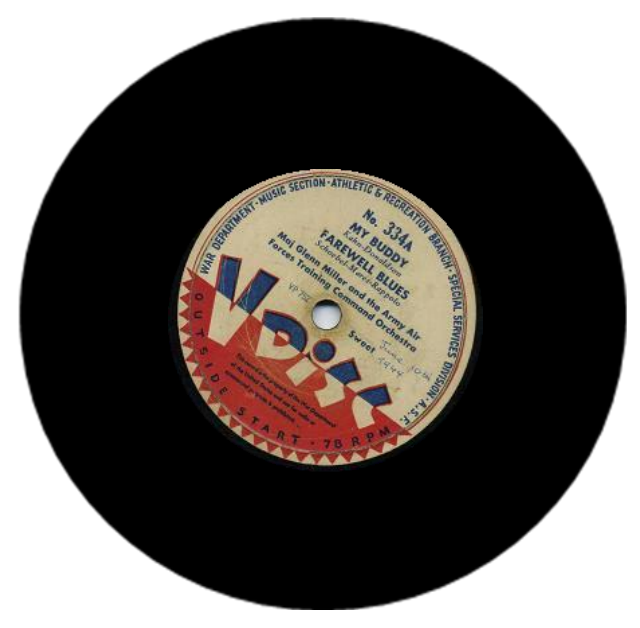

Special Services The Victory Disc or "V-Disc" 1943-1948

In 1949, shortly after the war, the Chief of Special Services assumed full responsibility for the supervision of all Army bands. One year later, in 1950, The Adjutant General of the Army was assigned formal proponency for Special Services to include the Army band program. Concurrently, the Special Services Department of The Adjutant General's School was 
established on July 15, 1950, at Fort Lee, Virginia, and became responsible for training officers and enlisted personnel in such things as service club operations, recreational sports, music, library services, hobbies, and leadership of special services companies.

\section{Demobilization of the World War II Army}

In summer, 1944, nearly a year before the end of hostilities, Lieutenant General Brehon Somervell, Commander, Army Service Forces, gave fair warning to his 300 top-ranking officers concerning the surge of activity soon to be associated with the demobilization of the multi-million man and woman Army of World War II. "We will have to put the car into reverse without even coming to a halt," said Somervell. In the "laborious process of demobilization ... we will find ourselves in the middle of a storm that will make everything else that we have gone through seem like a summer zephyr. Every family in America will want its sons and daughters turned loose first... we will have to steel ourselves against the distraction of the whooping and hollering of many souls who think the war is over." ${ }^{37}$

At its peak, soldiers and civilians performing the various duties of The Adjutant General's Department during the war numbered nearly 78,000 , none of which were more fully employed than the many who worked at the separation centers scattered around the country. Under immense pressure to quickly and without loss of record transition soldiers back into civilian life, Adjutant General's Department personnel ultimately succeeded in discharging more than six million soldiers at a rate of about 500,000 a month. ${ }^{38}$ The number of separation centers eventually numbered 155 , all of which had been used previously as reception centers to process soldiers into the wartime Army. The first five were established at Forts Dix, 
McPherson, Sheridan, and Sam Houston, and the Presidio of Monterey. As a last stop on the journey back home, soldiers received a physical examination, necessary medical treatment, travel and regular pay, and transition services that included job counseling and other advice on life after the military. ${ }^{39}$

Officers of the Adjutant General's Department who assisted in the effort called it "the greatest administrative task in Army history" and was accomplished at the same time as other essential services such as postal, rehabilitation of military prisoners, recruiting, Army printing and publication, and the maintenance, preservation, and disposition of literally millions of personnel records continued. The records from the Separation Centers, wrote one officer, came daily in "car loads, packed in boxes; at times stacked to the ceiling in the branches charged with their disposition." Upon receipt separation records had to be filed with each individual's induction records. The complete personnel record was then transported to the Records Administration Center in St. Louis, Missouri, for permanent keeping. ${ }^{40}$

\section{Establishment of The Adjutant General's Corps}

The growth of the "Cold War" military establishment following World War II necessitated the unprecedented peacetime expansion of the U.S. Army. Nothing exemplified that fact more than the permanent establishment of a specialized branch of service dedicated to peforming the increasingly sophisticated business of military personnel and administrative operations. Crafted from the lessons of World War II and the emerging personnel requirements of a global U.S. military commitment, the Army Organization Act of 1950 established The Adjutant General's Corps as a 
"basic branch" of service. With branch status came the obligation to prepare for war in peacetime - training soldiers in the specialty and developing personnel doctrine and unit structure and organization integral to the support of Army operations around the world. Consequently, those who served The Adjutant General of the Army were no longer detailed into the duty but became members permanently assigned to The Adjutant General's Corps, military specialists in personnel and administration. ${ }^{41}$

\section{The Adjutant General's Corps and the Cold War 1950-1991}

World War II defined the nature and scope of the The Adjutant General's Corps mission for the next 50 years. Major reorganizations or realignments during the time period, however, would whittle away at the immensity of tasks the war had assigned the branch and personnel and administrative specialists in general. Some of these missions would remain the responsibility of personnel and administrative specialists while others would be assigned to generalists from other branches of the Army. Limited wars in Korea and Vietnam also limited the personnel and administrative mission relative to World War II. The Adjutant General's Corps performed most of the functions from the earlier era, but on a much smaller scale. A total of 16 million, for example, served in World War II, while nearly six and nine million served in Korea and Vietnam respectively. ${ }^{42}$ The scale of operations relative to the basic wartime functions of the Adjutant General's Corps (replacement operations, strength accounting, casualty reporting, postal operations, personnel management, personnel support services, and special services to include Army bands) was significantly smaller. Although 
the Army would grow to include as many as 1.5 million soldiers during the Cold War, a common theme of the entire period was the need to reduce the number of troops necessary to support them. For The Adjutant General's Corps whose basic function was to support commanders and troops, this meant finding ways either through technical innovation or organizational efficiency to perform essential support services while requiring fewer soldiers to do so.

\section{The Adjutant General's Doctrine and Review Board}

The key to this process was the implementation of the Army's "combat development" program that emerged in the early years of the Cold War. As a basic branch of the Army, The Adjutant General's Corps, like the combat arms and other specialty branches, became charged with preparing specialists for war in time of peace, a task that required the writing of doctrine and the development of equipment and unit organizations based upon it. Further, the branch became responsible for training its soldiers in the skills, knowledge, and tasks necessary to perform the duties articulated by that doctrine and an understanding of The Adjutant General's wartime mission.

In August 1955 The Adjutant General established The Adjutant General's Doctrine and Review Board in the Pentagon, an agency focused on the development of Army personnel and administrative doctrine, equipment, and organizations tailored to meet the expected challenges of future combat. Later moved to Fort Benjamin Harrison to be collocated with The Adjutant

General's School, the Board continued to operate under the direct jurisdiction of the The Adjutant General of the Army. ${ }^{43}$ Major General John 
A. Klein, The Adjutant General, appointed Colonel Martin C. Pertl to be the first "President" of the Board. Within the Board's overall mission was the need to sponsor field exercises designed to test doctrine, organization, training, and equipment where the responsibilities and functions of The Adjutant General's Corps were involved. The Board's early projects included the development of an efficient method to report unit strength following a nuclear attack; development of an expandable van for use as a field office; centralizing personnel record-keeping functions, simplifying the casualty reporting process, studying the implications of the personnel reporting system on unit efficiency, improving postal system techniques and procedures, and streamlining procedures to receive and process individual replacements. ${ }^{44}$

\section{The Adjutant General and the Army Reorganization of 1962}

In May 1962, command of The Adjutant General's Board and The Adjutant General's School passed from The Adjutant General of the Army to the new U.S. Army Combat Developments Command and the U.S. Continental Army Command (CONARC) respectively. The agencies remained at Fort Harrison, but their chain-of-command no longer included The Adjutant General. The commander of the "Adjutant General Agency," the former Adjutant General's Board, began reporting to the commander of the new Combat Developments Command headquartered at Fort Belvoir, Virginia. ${ }^{45}$ The commandant of The Adjutant General's School began reporting to the commander of CONARC headquartered at Fort Monroe, Virginia, the major command that became responsible for all Army training.

On June 28, 1962 the Fifth U.S. Army formalized the realignment of The Adjutant General's School by issuing General Order 93, an order of 
some historical significance. The order renamed the school and severed the command line that linked it to The Adjutant General. Instead of The Adjutant General's School, the school became the Adjutant General School, U.S. Army, affirming the fact that it did not belong to The Adjutant General any longer. ${ }^{46}$ With the reorganization assigning branch development to the commander of the Combat Development Command, The Adjutant General also relinquished possession of the branch that bore his name. With the formation of the U.S. Army Training and Doctrine Command in 1973, the Adjutant General Combat Development Activity (formerly the Adjutant General Agency) was merged into the structure and organization of the U.S. Army Soldier Support Center of which the Adjutant General School was a part. The commander of the Soldier Support Center became responsible for both training and combat developments effecting the Adjutant General's Corps and the Army's personnel and administrative community as a whole.

The realignment of combat development and training activities resulted from "Project 80," a study sponsored by Secretary of Defense Robert S. McNamara and part of a major reorganization of the Army. Although surviving the reorganization that eliminated the offices of the Quartermaster General, Chief of Ordnance, and Chief Chemical Officer, The Adjutant General experienced a considerable reduction in his authority and span of control. In addition to training and combat development, The Adjutant General also lost much of the military personnel management function to the new Office of Personnel Operations (OPO), organized under the Deputy Chief of Staff for Personnel (DCSPER). ${ }^{47}$ OPO since 1962 has been renamed on four occasions to reflect the Army's continuing intent to centrally manage the career development of officer and enlisted personnel. In 1973, OPO inherited the remaining personnel management functions of 
The Adjutant General - separations, personnel records, promotions, and appointments -- and was reconfigured as the Military Personnel Center (MILPERCEN). ${ }^{48}$ In December 1988, MILPERCEN became the Total Army Personnel Agency (TAPA), followed one year later with, yet, another change -- the Total Army Personnel Command (TAPC). In October 2003 TAPC became the U.S Army Human Resources Command (HRC).

The mission of the Army's Adjutant General was further circumscribed in 1985 with the transfer of the Morale, Welfare, and Recreation (MWR) and information management missions to newly established staff officers within the Department of the Army. MWR (the old Special Services mission) was transferred to the U.S. Army Community and Family Support Center, a field operating agency that fell directly under the Deputy Chief of Staff for Personnel. Information management to include records management, a large part of The Adjutant General's administrative function, was transferred to the newly created Office of the Assistant Chief of Staff for Information Management and Information Systems Command. ${ }^{49}$ The following year on November 17, 1986, the Chief of Staff of the Army realigned The Adjutant General from the Army Staff to the Military Personnel Center (MILPERCEN). ${ }^{50}$ The office of The Adjutant General now found itself inside of a larger organization that used to be inside of it.

\section{The Adjutant General's Corps Regiment}

On June 7, 1987, Colonel Frank C. Foster, Jr, Commandant of the Adjutant General School, hosted activation ceremonies of the Adjutant General's Corps Regiment as part of the phased plan to adopt a regimental system of organization for the entire U.S. Army. Events on that day were preceded by months of planning and preparation aimed at creating programs intended to strengthen the bonds of affiliation among members of the 
Adjutant General's Corps. The U.S. Army Regimental System, approved by the Chief of Staff of the Army in 1981, declared service schools the "homes" of their respective branches and school commandants chiefs and proponent managers of their respective branches. Upon activation of the Adjutant General's Corps Regiment, Colonel Foster assumed responsibility for all development affecting the Adjutant General's Corps to include the career and professional development of more than 100,000 active duty, Reserve, and National Guard soldiers representing the Army's personnel community.

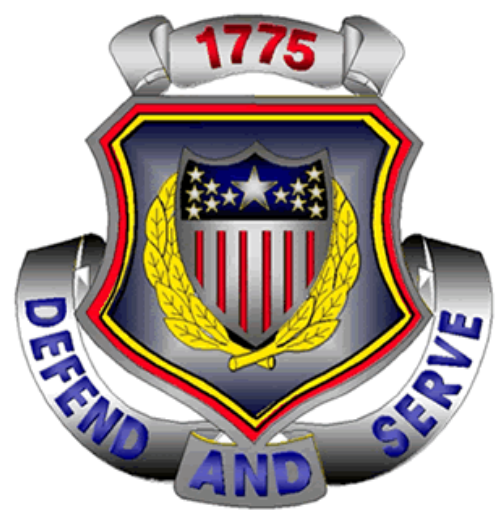
The Regimental Crest
with the Corps motto

"Defend and Serve"

The establishment of the Adjutant General's Corps Regimental Association (AGCRA) and its corresponding chapters around the world served to foster esprit de corps and fraternal association among members of the regiment. Among the many activities in support of those aims was the creation of an awards program that included the Major General Horatio Gates Medal bestowed upon members of the regiment for exemplary achievement or service. Recipients of the first awards on Regimental Day 1987 were Colonel Frank C. Foster, Commandant of the Adjutant General 
School; Major General (retired) Verne L. Bowers, former The Adjutant General of the Army and honorary Colonel of the Regiment; Sergeant Major (retired) Dan P. Daly, Honorary Sergeant Major of the Regiment; Donald E. Hess, Honorary Warrant Officer of the Regiment; Major General William G. O'Leksy, Director of Military Personnel Management; Major General Maurice O. Edmonds, Commander, U.S. Army Soldier Support Center and Fort Benjamin Harrison; Brigadier General Robert L. Dilworth, The Adjutant General; and Brigadier General Ronald E. Brooks, Commander, Personnel Information Systems Command. ${ }^{51}$

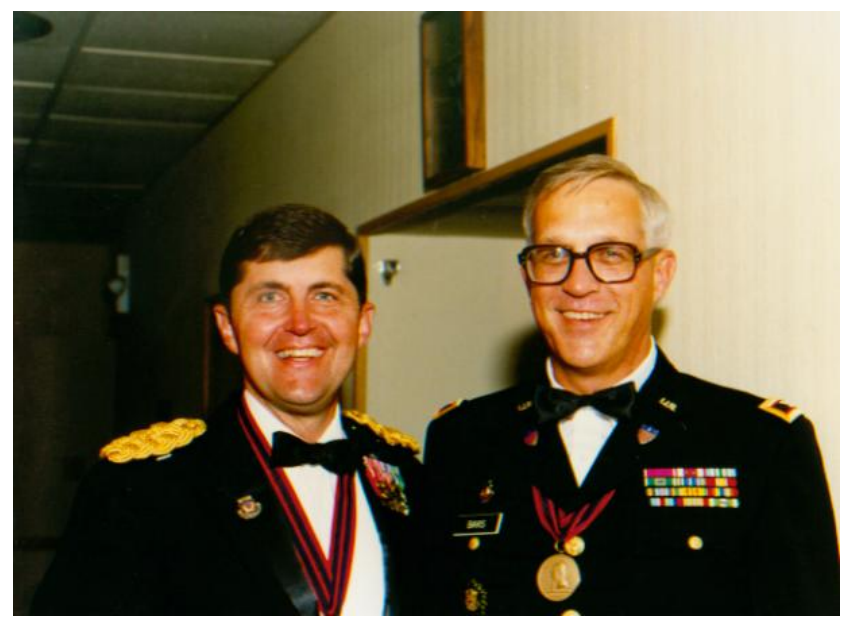

Colonel Frank C. Foster, Jr., Commandant, Adjutant General School on the left with fellow Adjutant General officer Colonel Robert J. Bavis. Each wears the Major General Horatio Gates Medal awarded to distinquished members of the Regiment.

\section{The Adjutant General's Corps and the Army of Excellence Redesign}

Perhaps the most dramatic restructuring of Adjutant General's Corps units and organizations since the beginning of World War II followed a 29 October 1984 message from the Deputy Chief of Staff for Personnel (DCSPER) directing the Adjutant General's Corps and other support 
branches to significantly "reduce the cost of business" to enable the Army to meet its strategic objective of adding two new "light" infantry divisions to the overall force structure. Quite simply this meant developing the means and methods to accomplish the Adjutant General mission with far fewer soldiers. The new "Army of Excellence" (AOE), said the DCSPER, would move "the personnel community into uncharted territory" requiring the use of computer hardware and software to compensate for reduced manning levels, the redesign of a major portion of the personnel management system, and the reorganization of most personnel and administrative units.

Based upon the loss of more than 3,000 personnel spaces, the Adjutant General's Corps had to revise doctrine, restructure units, and develop new equipment and training programs to support the structural changes. The transformation of the Adjutant General's Corps resulted in the elimination of Adjutant General companies in the division, and consolidation of the division G-1 and Adjutant General (AG) positions, functions previously distinguished by a general understanding that G-1s formulated and managed personnel policy and programs while Adjutant General technicians implemented them. Adjutant General personnel and functions considered essential in support of the division commander remained with the G1/AG. Remaining positions were embedded in new corps-level Personnel Service Companies (PSC) commanded by a Corp Personnel Group commander who served also as the corps Adjutant General. At the top of the AOE personnel structure was a Theater Personnel Command commanded by a Brigadier General. Eventually, battalion and brigade S-1 positions would be designated for Adjutant General's Corps personnel. The 1989 publication of FM 12-6, Personnel Operations, signified the completion of the Adjutant General's Corps transition to its 
AOE structure, the structure deployed to support the U.S. Army during Operations Desert Shield and Storm, 1990-1991; operations in the Balkans in the mid-1990s, and Operations Iraqi Freedom and Enduring Freedom in 2001-2003.

The new AOE structure tended to blur the line distinquishing traditional G-1 general staff functions from the special staff functions performed by the Adjutant General that had been in place since the appointment of the first assistant chief of staff, G-1 in 1921. However, the changes were not entirely new. During the Vietnam era, Major General Verne L. Bowers, The Adjutant General of the Army (1971-1975) served as the Deputy Chief of Staff, Personnel and Administration for the U.S. Army, Vietnam (USARV) from March 1969 - September 1970. Set up in July 1965, USARV became the logistical command headquarters for the U.S. Army whose commander served also as deputy commander of the Military Assistance Command, Vietnam (USMACV). As one of two deputy chiefs of staff under the USARV commander, Major General Bowers supervised the theater G-1, Adjutant General, Chaplain, Comptroller, Provost Marshall, Staff Judge Advocate, Inspector General, information officer, data systems manager, public affairs officer, civilian personnel director, headquarters commandant, and post commander. ${ }^{52}$

The transformation of the Adjutant General's Corps under AOE resulted in a broader acceptance of Adjutant General's Corps officers as military experts in both personnel policy and the technical aspects of personnel operations. As more Adjutant General's Corps officers served as battalion and brigade S-1s and division G-1s, positions previously assigned to personnel generalists among the combat arms community, senior leaders 
of the Army increasingly began turning to the Adjutant General's Corps as representative of both.

Since the advent of AOE, four Adjutant General's Corps officers have served either as the Deputy Chief of Staff for Personnel (DCSPER) or Deputy Chief of Staff, G-1, the highest ranking personnel officer in the Army. Prior to AOE, no officer in the Adjutant General's Corps had been selected for the post. The first, Lieutentant General Allen K. Ono, was appointed in June 1987 as AOE was beginning to transform the Adjutant General's Corps. Since then, Frederick E. Vollrath (1996), Timothy J. Maude (2000), and Michael D. Rochelle (2006) have followed Ono into the job. Further, the appointment of Major General Sean J. Byrne in 2006 as the commander of the Army's Human Resources Command marks the first ever appointment of an Adjutant General's Corps officer to that post.

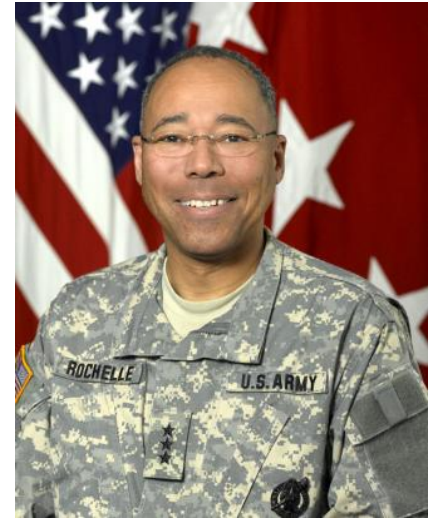

Lieutenant General Michael D. Rochelle Deputy Chief of Staff G-1, U.S. Army June 2006 -- 2009

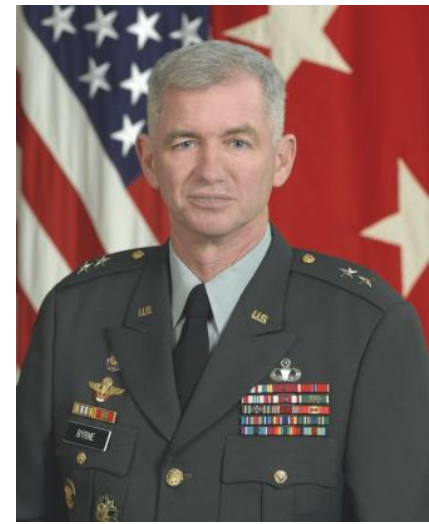

Major General Sean J. Byrne Commander,

U.S. Army Human Resources Command 2006-2010

\section{Beyond the Cold War}




\section{The Adjutant General's Corps in the $21^{\text {st }}$ Century}

Until 11 September 2001 and the beginning of the Global War on Terror, two themes had dominated the transition of the U.S. Army from its late $20^{\text {th }}$ Century Cold War posture to one considered relevant to the future and the national security needs of the $21^{\text {st }}$ century. The first theme originated from the percieved need to build a lighter, more versatile, fulldimensional military capability to address the presence of emerging multiple threats in the new century; the second from the "Revolution in Military Affairs," and the impact of digital computer technology on the operational Army of the future. Together the two themes were about change and the impending post-Cold War transformation of the Army, the Adjutant General's Corps included. As Lieutenant General Frederick C. Vollrath, DCSPER of the Army, announced to leaders of the Adjutant General's Corps in April 1997, "Change is hard, and the normal human reaction is to deny it. But, if change scares you, you need to get out of here." ${ }^{, 53}$ Vollrath's warning order to fellow members of the Adjutant General's Corps predicted the course of Army force development in the years ahead -- a complete and thorough transformation of the U.S. Army based upon the changing nature of the "threat" and the impact of computer technology on Army doctrine, organizations, training, leader development, equipment, and the soldiers themselves.

\section{Personnel Transformation and the Adjutant General's Corps}

Transformation of the Adjutant General's Corps, the branch specific-dimension of the overall transformation of the Army, began with a basic revision of the concept used to describe its mission. Rather than "personnel" or "personnel and administration," the Adjutant General's 
Corps became the Army proponent for "human resources management," a term that was gaining greater currency within the civilian business world. As a concept Human Resource Management embraced not only the traditional personnel functions like hiring, firing, and the paying of employees and managing the paperwork thereof, but the staffing, training, and career management of people within the organization. A transformed Adjutant General's Corps would be committed to maximizing return on the Army's investment in the soldiers and civilians who composed the human capital of the organization.

The Army's readiness, said Lieutenant General Timothy J. Maude, Adjutant General's Corps Officer and Deputy Chief of Staff for Personnel in 2001, "is inextricably linked to the well-being of its people. Well-being is the human dimension of Army Transformation. It is the personal - physical, material, mental and spiritual - state of soldiers, civilians, retirees, veterans, and their families that contributes to their preparedness to perform and support the Army's mission." ${ }^{54}$ A transformed human resource management community, said Maude, would become "strategically responsive," developing the capability to provide "lifecycle personnel support across the entire spectrum of operations." The key, he continued, would be the development of a "multi-component, core data base" appropriate for all knowledge-based organizations of the future. For human resource strategy to be fully realized, "personnel information needed to be "easily and readily available to the commander and soldier." 55

\section{FM 1-0, Human Resources Support}


The publication of FM 1-0, Human Resources Support in February 2007, marked an important milestone in the transition of the Adjutant General's Corps from its Cold War posture to one that addressed the probable operational scenarios of the $21^{\text {st }}$ century. It represented new doctrine for a new age, "outlining the capabilities and responsibilities of HR [Human Resources] leaders and organizations as they operate across the full spectrum of conflict."

The new doctrine reflected the Adjutant General's Corps' intent to compliment the Army's strategic design of becoming a lighter, increasingly versatile, and more responsive military force. A truly transformed Human Resources Support capability, as Lieutenant General Maude projected in 2001, would through common easily accessible web-based programs be able to support commanders and soldiers in both active and reserve components of the Army. It would also necessitate the restructuring of Adjutant General's Corps assets to support "modularity" on the battlefield. Modularity as the structural basis for increasing versatility would enable commanders to tailor deployable and self-sustaining troop units that addressed the specific operational and tactical requirements at various points on the spectrum of conflict. The newest challenge for the Adjutant General's Corps and other combat service support organizations was to deploy and operate absent the cumbersome "stovepipe" organizations of the past that made each echelon of command dependent on the other to provide fullservice support. As the Army of the early $21^{\text {st }}$ century transitioned to a "brigade-centric" force, the task of the Adjutant General's Corps and the Human Resources Support community in general has been to develop the means and the methods to sustain the combat brigade without the traditional 
division, corps, and theater-level organizations upon which it used to depend. ${ }^{56}$

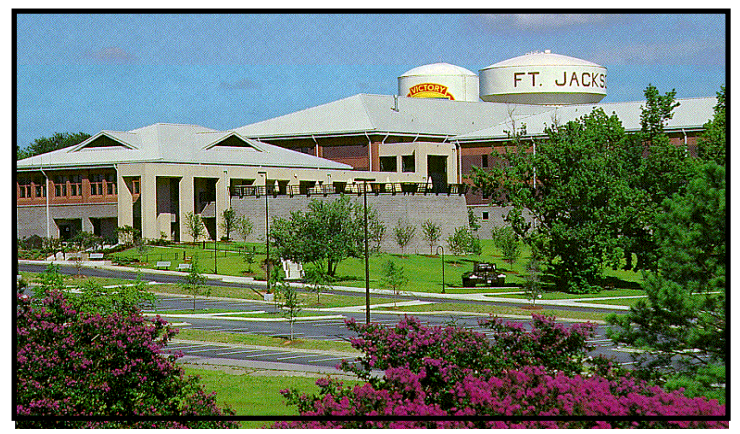

Gates-Lord Hall, Fort Jackson, SC Home the Adjutant General School 1995-present

Despite significant structural and technological change of the postCold War period, the overall mission of the Adjutant General's Corps has remained fairly constant since the beginning of the 20th Century. The growing human and technical complexities of manning and sustaining a highly specialized and technically sophisticated modern Army required equally specialized and technically sophisticated soldiers who became responsible for creating and operating the systems relative to "personnel sustainment" of the Army, the mission assigned The Adjutant General of the Army by the National Defense Act of 1916.

The current edition of FM 1-0 (2010) identifies four core compentencies and related "key functions" as the basis for personnel sustainment and human resources support in the $21^{\text {st }}$ Century. The four competencies include (1) Man the Force, (2) Provide Human Resources Services, (3) Coordinate Personnel Support, and (4) Conduct Human Resources Planning and Operations. ${ }^{57}$ 
It is highly probable that Major General Robert C. Davis, Theater Adjutant General for General John J. Pershing's American Expeditionary Force during World War I, would readily recognize the current core competencies and their associated functions of today's Adjutant General's Corps. He would also have no problem understanding the word "transformation." Davis was primarily responsible for building a theater personnel sustainment organization based upon a larger transformation of the Army and the Adjutant General's Department in early years of the $20^{\text {th }}$ century. From a highly independent bureau system with a myriad of overlapping functions, the U.S. Army transformed itself into a more highly unified command structure headed by a Chief of Staff and a General Staff. The Adjutant General of the Army under the new organization lost stature as a powerful bureau chief, but as one of the War Department's special staff gained principal responsibility for the personnel sustainment of the Army in peace and war. The thing Davis would not recognize, however, are the terribly slimmed down organizations and the highly efficient digital information systems that enable today's leaders to accomplish the HR support mission in much less time with far fewer people.

\section{Human Resources Support}

A Sustainment Warfighting Function

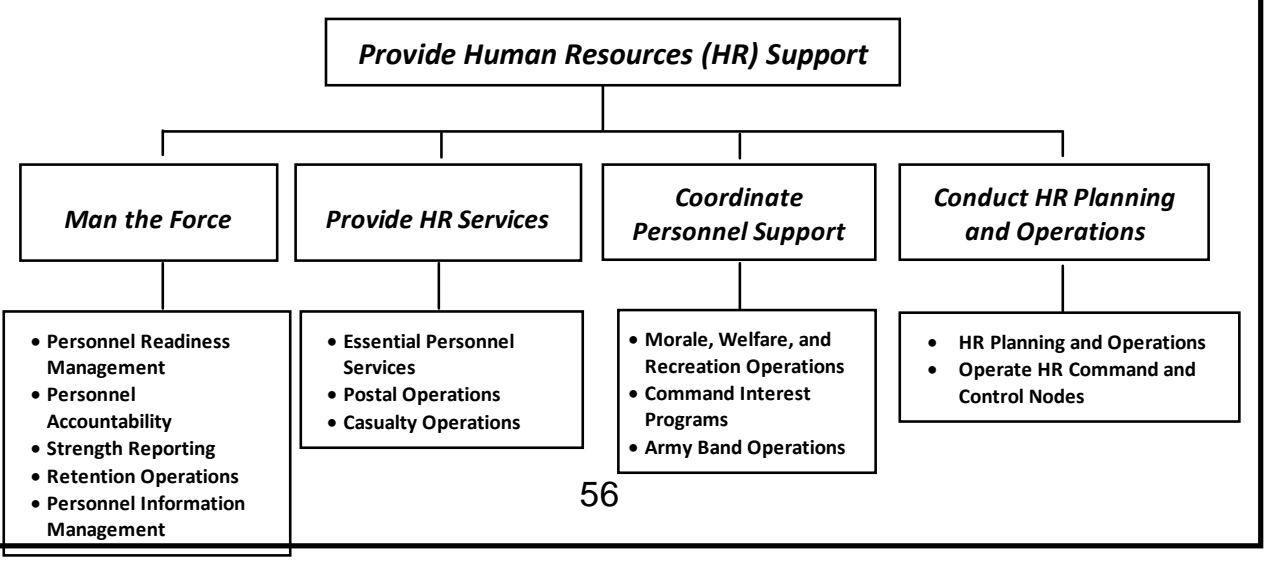




\section{The 4 HR Core Competencies and the Key Functions of Each ${ }^{58}$}

\section{Global War on Terror: 2001-2013}

On 11 September 2001, 126 military personnel in the Office of the Deputy Chief of Staff for Personnel died as a result of the terrorist attack on the Pentagon. Many of the victims were Adjutant General's Corps officers and enlisted personnel. The Army's Deputy Chief of Staff for Personnel, Lieutentant General Timothy J. Maude was among them. Maude became the highest ranking officer to lose his life in action since Lieutenant General Simon B. Buckner, Jr. was killed during World War II at the Battle of Okinawa, 18 June 1945.

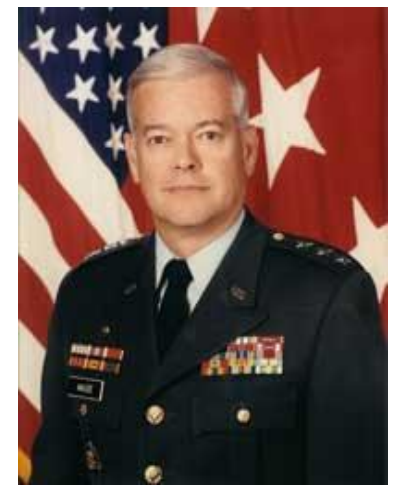

Lieutenant General Timothy J. Maude Deputy Chief of Staff for Personnel August 2000 - September 2001

The subsequent Global War on Terror that generated deployment of the U.S. Army to Afghanistan and Iraq has taken the life of other soldiers of the Adjutant General's Corps. Their loss is indicative of a truly unconventional war that proceeds without "front lines" and continues to take 
the life of soldiers committed to supporting commanders and troop units in the respective theaters of operation. ${ }^{59}$ This brief history is dedicated to them and the many other soldiers of the Adjutant General's Corps who throughout the history of our nation have served to serve others. 


\section{The Adjutant Generals of the Army \\ 1775-2013

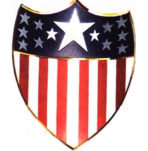

\section{Adjutant Generals}

1. Maj. Gen. Horatio Gates

1775-1776

2. Col. Joseph Reed

\section{Acting Adjutant Generals}

3. Brig. Gen. Arthur St. Clair

4. Brig. Gen. George Weedon

5. Col. Morgan Connor

\section{Adjutant Generals}

6. Col. Timothy Pickering

7. Col. Alexander Scammel 1778-1781

8. Brig. Gen. Edward Hand $1781-1783$

Acting Adjutants or Adjutants/ Inspectors

9. Maj. William North --- 1783-1787

10. Lieut. Ebenezer Denny --------------------------- 1787-1790

11. Lieut. John Pratt -------------------------------- 1790-1791

12. Lieut. Colonel Winthrop Sargent 1791

13. Lieut. Ebenezer Denny --------------------------- 1791-1792

14. Lieut. Henry De Butts --------------------------- 1792-1793

15. Maj. Michael Rudolph

1793

16. Capt. Edward Butler $1793-1794$

17. Maj. John Mills 1794-1796

18. Maj. Jonathan Haskell 1796

19. Capt. Edward Butler $1796-1797$

20. Maj. T. H. Cushing 1797-1798

Adjutant Generals

21. Brig. Gen. William North

1798-1800

Adjutants/ Inspectors

22. Col. T. H. Cushing

1800-1807

23. Maj. Abimael Y. Nicoll 1807-1812 
Acting Adjutant Generals

24. Lt. Col. Alexander Macomb 1812

Adjutant General

25. Brig. Gen. T. H. Cushing

1812-13

Adjutants and Inspector Generals

26. Brig. Gen. Zebulon Pike

27. Brig. Gen. W. H. Winder

1814

28. Brig. Gen. Daniel Parker

1814-1821

Adjutant Generals

29. Col. James Gadsden

$1821-1822$

\section{Acting Adjutant Generals}

30. Capt. C. J. Nourse

$1822-1825$

\section{Adjutant Generals}

31. Maj. Gen. Roger Jones

1825-1852

32. Col. Samuel Cooper

1852-1861

33. Brig. Gen. Lorenzo Thomas

1861-1869

34. Brig. Gen. E. D. Townsend

$1869-1880$

35. Brig. Gen. R. C. Drum

1880-1889

36. Brig. Gen. J. C. Kelton

1889-1892

37. Brig. Gen. Robert Williams

1892-1893

38. Brig. Gen. G. D. Ruggles

1893-1897

39. Brig. Gen. Samuel Breck

$1897-1898$

40. Maj. Gen. Henry C. Corbin

1898-1904

Military Secretary ${ }^{1}$

41. Maj. Gen. Fred C. Ainsworth

1904-1907

\section{Adjutant Generals}

42. Maj. Gen. Fred C. Ainsworth

1907-1912

43. Brig. Gen. William P. Hall

1912

44. Brig. Gen. George Andrews

$1912-1914$

45. Maj. Gen. Henry P. McCain

1914-1918

46. Maj. Gen. Peter C. Harris

1918-1922

47. Maj. Gen. Robert C. Davis

1922-1927

\footnotetext{
1 A War Department reorganization in 1904 consolidated the Adjutant General Office (AGO) with the Record and Pension Office and designated its head as the Military Secretary. In 1907 the position was redesignated under the more prestigious title "The Adjutant General" of the Army (TAG).
} 
48. Maj. Gen. Lutz Wahl

1927-1928

49. Maj. Gen. Charles H. Bridges

1928-1933

50. Maj. Gen. James F. McKinley

1933-1935

51. Maj. Gen. Edgar T. Conley

$1935-1938$

52. Maj. Gen. Emory S. Adams

1938-1942

53. Maj. Gen. James A. Ulio

1942-1946

54. Maj. Gen. Edward F. Witsell

1946-1951

55. Maj. Gen. Wm. E. Bergin

1951-1954

56. Maj. Gen. John A. Klein

1954-1956

57. Maj. Gen. Herbert M. Jones

1957-1958

58. Maj. Gen. R. V. Lee

1958-1961

59. Maj. Gen. J. C. Lambert

1961-1966

60. Maj. Gen. Kenneth G. Wickham

1966-1971

61. Maj. Gen. Verne L. Bowers

1971-1975

62. Maj. Gen. Paul T. Smith

1975-1977

63. Maj. Gen. J. C. Pennington

1977-1981

64. Maj. Gen. Robert M. Joyce

1981-1984

65. Brig. Gen. Donald J. Delandro

1984-1985

66. Brig. Gen. Mildred E. Hedberg

1985-1986

67. Brig. Gen. R. L. Dilworth

1986-1988

68. Brig. Gen William J. Meehan

1988-1990

69. Brig. Thomas F. Sikora

1990-1991

70. Brig. Gen. Patricia P. Hickerson

1991-1994

71. Brig. Gen. Stephen Smith

1994-1995

72. Brig. Gen. Earl M. Simms

1995-1998

73. Brig. Gen. Kathryn Frost

1998-2002

74. Brig. Gen. Gina S. Farrisee

2002-2004

75. Brig Gen Eric Porter

2004-2006

76. Brig Gen Reuben D. Jones

2006-2009

77. Brig Gen. Richard P. Mustion

2009-2011

78. Brig. Gen. Jason T. Evans

2011-2013

79. Brig. Gen. David K. MacEwen 2013-present

\section{COMMANDANTS/ DIRECTORS U.S. ARMY ADJUTANT GENERAL SCHOOL 1943-2013}


1. BG Herbert C. Holdridge -----------o- 1942-1943

2. COL Lathrop B. Clapham --a- 1943-1947

3. COL Harris F. Scherer --- 1947-1950

4. COL Leland S. Smith 1950-1954

5. COL Leslie W. Stanley

1954-1955

6. COL Earl W. Bosgieter

1955-1959

7. COL Kenneth G. Wickham

1959-1961

8. COL A. L. Ransone --- 1961-1963

9. COL Robert G. Platt ---on 1963-1965

10. COL Nathan H. Hixson -- 1965-1969

11. COL Jack T. Pink --- 1969-1971

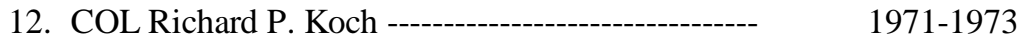

\section{DIRECTORS $^{2}$}

1. COL Billy L. Oliver -- 1973-1974*

2. COL Phillip A. Serrin II --- 1980-1981

3. COL William E. Duey --- 1981-1982

4. COL Louis Rose -- 1982-1983

5. COL Lawrence N. Brockway -----------------1983

6. COL Charles O. Coffman -- 1983-1984

7. COL Louis Rose --o-1984-1985

\section{COMMANDANTS}

13. COL Mary C. Willis -

14. COL Frank C. Foster, Jr. -- 1986-1990

15. COL James R. Daugherty-- 1990-1991

16. COL Earl M. Simms -- 1991-1992

17. COL Michael J. Goodman -----o- 1992-1993

18. COL Steve B. Strippoli -- 1993-1994

19. COL Earl M. Simms ---1994-1996

20. COL Gary L. Gresh --19-19-1998

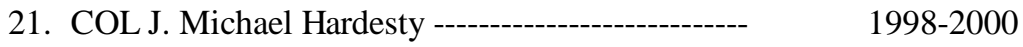

22. COL Ruth Collins --- 2000

23. COL Michael R. Molosso -- 2000-2002

24. COL Donald A. Bartholomew --a-2002-2004

${ }^{2}$ From 1974-1980 the Adjutant General School was restructured into departments within the U.S. Army Institute of Administration. 
25. COL Brent A. Johnson

2004-2005

26. COL Rose A. Walker

2005-2006

27. COL Wanda E. Wilson

2006-2007

28. COL Richard P. Mustion

-2007-2008

29. COL Robert L. Manning 2008-2012

30. COL Todd Garlick 2012-present 


\section{END NOTES}

${ }^{1}$ Robert K. Wright, Jr., The Continental Army, (Washington: U.S. Government Printing Office, 1983), 30; Boatner, Mark M. III Encyclopedia of the American Revolution (Mechanicsburg, PA: Stackpole Books), 1994, 12.

${ }^{2}$ George Washington, General Orders, January 8, 1776, cited in Charles H. Lesser, editor, The Sinews of Independence: Monthly Strength Reports of the Continental Army (Chicago: University of Chicago Press, 1976), xviii.

${ }^{3}$ Russell F. Weigley, History of the United States Army (New York: Macmillan Press, 1967), 323: Postmaster General Charles Emory Smith to Elihu Root, cited in Graham A. Cosmas, An Army for Empire: The United States Army in the Spanish-American War (Columbia: University of Missouri Press, 1971), 146.

${ }^{4}$ Major Livingston Watrous, "A Brief History of the Adjutant General's Department" (Governors Island, NY: The Recruiting Publicity Bureau, 1927), 7; James B. Fry, "A Sketch of Organization of the Adjutant General's Department, United States Army, 1775-1875 (New York: Private Publication, 1875), 35, 61

${ }^{5}$ A brevet rank is the result of temporary promotion of a military officer without an increase in pay.

${ }^{6}$ James B. Fry, "The Adjutant General's Department." Included in Theophilus F. Rodenbough and William L. Haskin, The Army of the United States Historical Skethces of Staff and Line with Portraits of Generals-in-Chief (New York: Maynard, Merrill, and Company, 1896), 8.

${ }^{7}$ See the "Soldiers Home History," www.lincolncottage.org/history/sh/history: U.S. Soldiers' and Airmen's Home (USSAH), Washington, D.C., www.defenselink.mil/specials/heroes/history 1.html. Today it is known as the U.S. Soldiers' and Airmen's Home.

${ }^{8}$ The Tenure of Office Act (March 2, 1867), enacted over the veto of President Andrew Johnson, denied the President of the United States the power to remove from office anyone who had been appointed by the President by and with the advice and consent of the United States Senate unless the Senate also approved the removal; Robert C. Kennedy, "The Impeachment of Andrew Johnson (Lorenzo Thomas)," Harper's Weekly, impeachandrewjohnson.com/11BiographiesKeyIndividuals/LorenzoThomas.htm.

9 “A Brief Record of The Adjutant General -- Office, Department, and Corps," no author, no date, 13; "Background Material for the History of the Adjutant General's Office and the Adjutant General's Corps," prepared by order of Major General Edward F. Witsell, The Adjutant General, 25 July 1947.

${ }^{10}$ W. E. Burghardt Du Bois, “The Freedman's Bureau,” Atlantic Monthly, 87, 1901, 354-365; Elaine C. Everly, Freedmen's Bureau Records: An Overview, Prologue Magazine, Summer, 1997. 
${ }^{11}$ James E. Hewes, From Root to McNamara: Army Organization and Administration, 1900-1963 (Washington, DC, Government Printing Office, 1975), 26.

12 "That the Chief of Staff, under the direction of the President or of the Secretary of War, under the direction of the President, shall have supervision of all troops of the line and of the Adjutant-General's, Inspector-General's, Judge-Advocate's, Quartermaster's, Subsistence, Medical, Pay, and Ordnance Departments, the Corps of Engineers, and the Signal Corps, and shall perform such other military duties not otherwise assigned by law as may be assigned to him by the President." See Chap 558, Section 4, "An Act to Increase the Efficiency of the Army," 14 February 1903, United States Statutes at Large, Fifty-seventh Congress, Vol. 32 Part 1, 830-831.

${ }^{13}$ Watrous, “A Brief History of the Adjutant General's Department," 19-20. In 1889, the War Department transferred responsibility for military personnel records of formerly serving soldiers from the Adjutant General's Department to the Records and Pensions Office under the Surgeon General, thereby joining personnel with medical records of former soldiers. See Clyde Halstead Van Tyne and Waldo Gifford Leland, Guide to the Archives of the Government of the United States in Washington, (Washington: Carnegie Institution of Washington, 1904), 106-108.

${ }^{14}$ Captain W. D. Conner, "Organization and Duties of the Staff," Department of Military Art, Infantry and Cavalry School, Lecture No.3, Organization and Tactics, November 22, 1904, 20.

${ }^{15}$ Watrous, “A Brief History of the Adjutant General's Department,” 20-21.

${ }^{16}$ Committee on the Classification of Personnel, The Personnel System of the United States Army, Vol. 1, History of the Personnel System (Washington, DC: Government Printing Office, 1919), 56.

${ }^{17}$ G. Larson, "Armed Services Vocational Aptitude Battery" and F. McGuire, "Army Alpha and Beta Tests of Intelligence" in R.J. Sternberg (Ed.), Encyclopedia of Intelligence (New York: Macmillan, 1914), Vol. 1, 121 -129.

${ }^{18}$ Committee on Classification of Personnel in the Army, The Personnel System of the United States Army, Vol. I, History of the Personnel System (Washington, DC: Government Printing Office, 1919), 3-4.

${ }^{19}$ Watrous, “A Brief History of the Adjutant General's Department," 22-23.

${ }^{20}$ Major General James G. Harbord, Leaves from a War Diary, (New York: Dodd, Mead \& Company, 1931), 368.

${ }^{21}$ Watrous, "A Brief History of the Adjutant General's Department," 23-26.

${ }^{22}$ Ibid., 27. 
${ }^{23}$ Ibid., 29.

${ }^{24}$ James A. Ulio, "Scope of our Adjutant General's Department, Our Army, XVII (Jan 1945), 7-10, 26-29; "World War II(1939-1945): Domestic Course," The Oxford Companion to American Military History, John Whiteclay Chambers II, editor (New York; Oxford University Press, 1999), 827

25 "Reorganization Manual of the Army Services Forces, 15 February 1943; cited in The Adjutant General, His Office and Department, A Short History, 1775-1947 (Washington, DC: Office of The Adjutant General, 1947), 121.

${ }^{26}$ War Department Circular 59, 2 Mar 1942.

${ }^{27}$ Charles R. Shrader, "U.S. Military Service and Casualties in Major Wars and Conflicts, 1775-1991," The Oxford Companion to American Military History, John Whiteclay

Chambers II, editor (New York: Oxford University Press, 1999), 849.

28 "The Adjutant General's Office and Department: A Short History, 1775-1947” (Washington, DC, Department of the Army, 1947), 127.

29 "Birthday of AG School Celebrated Yesterday," Harrisonian, June 15, 1956.

${ }^{30}$ Wikipedia, The Free Encyclopedia, en.wikipedia.org/wiki/CherylHoldridge; E. J. Kahn, "Comment," The New Yorker, September 17, 1955, 35.

${ }^{31}$ Fact Sheet; USASSC (ATSG-CSP); subj: Transfer of Personnel Proponency, 12 August 1986.

32 James Robert Mock, Cedric Larson, "Morale-The Soul of the Army," Teachers College Record, Volume 7 Number 62, 1941, p. 237-239

33 "No More "Y," Time Magazine, September 30, 1940.

${ }^{34}$ Howard C. Bronson, "Wartime Music Services," Music Educators Journal, Vol. 29, No. 1 (Sep. - Oct., 1942), 45, 56-57.

${ }^{35}$ See bands.army.mil/history/default.asp.

${ }^{36}$ Bronson, "Wartime Music Services."

37 “Soldiers' Return,” Time Magazine, August 21, 1944.

${ }^{38}$ Cited in "Background Material for the History of the Adjutant General's Office and the Adjutant General's Corps," Encl. no. 8, Strength - The AGD and AGO - On Key Dates, 24 June 1947. 
39 “Soldiers' Return"; John C. Sparrow, History of Personnel Demobilization in the United States Army (Washington, DC: U.S. Army Center of Military History, 1951), 201-203.

40 “The Adjutant General's Office and Department: A Short History, 1775-1947,” 162-163.

${ }^{41}$ Letter, Secretary of the Army to Congress, July 21, 1949; included in Analysis and Explanation of Army Organization Bill, 81st Congress, S. 2334, H.R. 5794 (Department of the Army, February 1950), 3-4.

${ }^{42}$ Shrader, "U.S. Military Service and Casualties in Major Wars and Conflicts, 1775-1991."

${ }^{43}$ Hewes, From Root to McNamara, 258-262.

44 "New TAG Board Is Founded Here," The Observer, September 16, 1955; "Colonel Pertl Heads New AG Board Here," The Harrisonian, September 14, 1956; "AG Board Active Throughout Year," The Harrisonian, January 2, 1959; Colonel M. C. Pertl, "TAG Board and ADPS," The Harrisonian, May 9, 1958: "AG Board Active Throughout Year," The Harrisonian, January 2, 1959; Ibid.; "Project Work Plans," The Adjutant General's Board (Fort Benjamin Harrison, Indiana, 1956), Tab I; Ibid.; "AG Board Conducts Division Troop Test," The Harrisonian, March 6, 1959.

45 "Reassignment for TAG Bd President," The Harrisonian, May 18, 1962; "Combat Developments Agency Activated Here," The Harrisonian, August 10, 1962.

${ }^{46}$ GO 93, Hq Fifth U.S. Army, June 28, 1962. GO 116, HQ, Fifth U.S. Army; Change in Status of Certain Fifth United States Army Table of Distribution Units, December 16, 1963, changed the name again to the U.S. Army Adjutant General School.

${ }^{47}$ Hewes, From Root to McNamara, 337-343.

${ }^{48}$ General Order No. 9; The United States Army Adjutant General Center, Headquarters, Department of the Army, Washington, DC, 26 March 1973.

${ }^{49}$ Karl E. Cocke, Department of the Army Historical Summary, Fiscal Year 1985 (Washington, DC: U.S. Army Center of Military History, 1995), 66-67.

${ }^{50}$ Memorandum, U.S. Army Chief of Staff (COS) to distribution; subj: Realignment of the Office of The Adjutant General, November 17, 1986.

${ }^{51}$ Captain David S. Niekerk, "Our Thanks is Worth its Weight in Gold, Soldier Support Advocate, July-December 1987, 4.

${ }^{52}$ Major General Verne L. Bowers, "Final Report, Deputy Chief of Staff, Personnel and Administration, Headquarters, US Army, Vietnam, 30 March 1969 - 10 September 1970," 10 September 1970, 1-2.

${ }^{53}$ Vollrath quoted in “Army Forces Gear Up For Warp-Speed Future," Fort Jackson Leader, Fort Jackson, South Carolina, April 1997. 
${ }^{54}$ Lieutenant General Timothy J. Maude, "Recruiting and Retaining Quality People and Improving their Well-Being,” Army, October 2001, 140.

${ }^{55}$ Maude, "Army Human Resources Management in the $21^{\text {st }}$ Century, Army, October 2000, 145; "DCSPER Vision Statement," 1775: The Journal of the Adjutant General's Corps Regimental Association, Vol. 10, No. 4, Spring, 2001, 5-6.

${ }^{56}$ FM 1-0, Human Resources Support, (Washington, D.C.: Department of the Army, 21 February 2007), 2-1.

${ }^{57}$ Field Manual 1-0, Human Resources Support, (Washington, DC, Department of the Army, 6 April 2010), 1-3.

${ }^{58}$ Ibid., 1-4.

${ }^{59}$ CSS Collective Training Division, Combined Arms Support Command, "Sustainment Fatality Demographics," 2 Nov 2002 - 1 July 2007, 5 October 2007. 